\section{Check for updates}

Cite this: New J. Chem., 2019, 43,5948

Received 21st December 2018, Accepted 20th March 2019

DOI: 10.1039/c8nj06451b

rsc.li/njc

\title{
New enantiopure binaphthyl-cinchona thiosquaramides: synthesis and application for enantioselective organocatalysis $\dagger$
}

\author{
Sándor Nagy, (DD a Gyula Dargó, (DD a Péter Kisszékelyi, (DD ${ }^{a}$ Zsuzsanna Fehér, (DD ${ }^{a}$

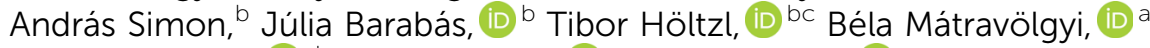 \\ Levente Kárpáti, (D) ${ }^{d}$ László Drahos, (D) Péter Huszthy (D) ${ }^{a}$ and József Kupai (D) *a
}

\begin{abstract}
This work presents the first successful applications of cinchona-thiosquaramides in asymmetric reactions. Binaphthyl-cinchona squaramides and thiosquaramides were synthesised, and then used as organocatalysts to promote the catalytic enantioselective Michael addition reaction of pentane-2,4dione to trans- $\beta$-nitrostyrene with excellent yields (up to $99 \%$ ) and enantioselectivities (up to $99 \%$ ee) at as low as $0.2 \mathrm{~mol} \%$ catalyst loadings. Thiosquaramides gave higher enantioselectivities (up to $92 \%$ ee) in conjugate addition reaction of lawsone to $\beta, \gamma$-unsaturated $\alpha$-keto ester than its oxo analogue, with high yields (up to $100 \%$ ). Also, only thiosquaramide could catalyse the aza-Diels-Alder addition reaction of 2-siloxydiene to benzylideneacetone. Furthermore, quantum chemical computations showed that the geometrical structure of binaphthyl-cinchona thiosquaramide is similar to that of squaramide.
\end{abstract}

\section{Introduction}

Over the last 20 years an explosive growth of research in the field of asymmetric synthesis has taken place. $^{1-5}$ The aim of enantioselective synthesis or catalysis is to produce enantiopure products (a single enantiomer as the ultimate goal) starting from achiral substrates by chiral reagents, catalysts or auxiliaries. The role of these chiral reagents or catalysts is to generate diastereomeric transition states leading to the formation of two enantiomers so that one of them is preferentially formed. In recent years binaphthyl compounds have found frequent applications in the design of various asymmetric organocatalysts, ${ }^{6-12}$ since the binaphthyl structure is an attractive platform for catalyst development, particularly in light of

\footnotetext{
${ }^{a}$ Department of Organic Chemistry \& Technology, Budapest University of Technology \& Economics, Szent Gellért tér 4, Budapest, 1111, Hungary. E-mail: jkupai@mail.bme.hu; Tel: +36-1463-2229

${ }^{b}$ Department of Inorganic \& Analytical Chemistry, Budapest University of Technology \& Economics, Szent Gellért tér 4, Budapest, 1111, Hungary

${ }^{c}$ Furukawa Electric Institute of Technology, Késmárk utca 28/A, Budapest, 1157, Hungary

${ }^{d}$ Laboratory of Plastics \& Rubber Technology, Budapest University of Technology \& Economics, Müegyetem rkp. 3., Budapest, 1111, Hungary

${ }^{e}$ MS Proteomics Research Group, Research Centre for Natural Sciences, Hungarian Academy of Sciences, Magyar Tudósok körútja 2, Budapest, 1117, Hungary $\dagger$ Electronic supplementary information (ESI) available: FT-IR, ${ }^{1} \mathrm{H},{ }^{13} \mathrm{C}, 2 \mathrm{D}$ NMR and MS spectra of new compounds, thermoanalytical measurements (TGA, DSC) of catalysts $\mathbf{1 a}$ and $\mathbf{1 b}$, chiral HPLC profiles of Michael and conjugate adducts and data of theoretical calculations. See DOI: 10.1039/c8nj06451b
}

their axially chiral characteristic. The enantiomeric atropisomers of 2,2'-substituted binaphthyls have been developed to exploit the axial dissymmetry induced by the restricted rotation about the biaryl bond. ${ }^{8}$ Application of binaphthyl unit as a chiral scaffold is well-established in asymmetric catalysis, especially the binaphthyl-based bifunctional mono-, bisthioureas, and cinchona-squaramides (Fig. 1) have been found beneficial in asymmetric Michael addition. ${ }^{13-16}$

Nowadays, squaramides have become a dominant core among hydrogen bond catalysts, ${ }^{17-21}$ thanks to their rigid four-membered ring, the appropriate distance between the donor hydrogens, and higher acidity. Very recently, Rawal et al. published $^{22}$ the first application of thiosquaramides, the thio analogues of squaramides, as asymmetric catalysts. In a recent review, the main benefits of thio analogues compared to those of squaramides, like increased aromaticity, higher acidity and greater solubility in nonpolar solvents, were summarised. ${ }^{23}$ Bifunctional thiosquaramides are a promising new class of catalysts, and their simple preparation procedure is expected to further expand the scope of reactions in hydrogen bonding catalysis. ${ }^{24}$
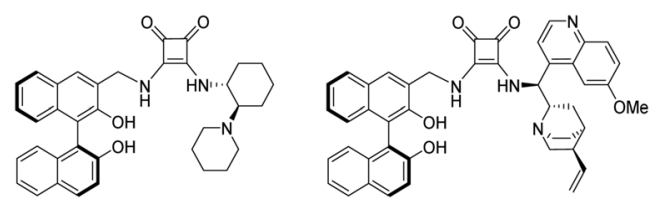

Fig. 1 Binaphthyl-based bifunctional squaramides. 
Stereodivergence in cooperative asymmetric catalysis with simultaneous involvement of two chiral catalysts is a persistent challenge in asymmetric catalysis. Depending on whether the orientation of the two chiral attachments is complimentary or opposed, stereochemical enhancement or stereochemically destructive interference might occur. The question of how two chiral catalytic units work in concert, surmounting the chiral match-mismatch issue, is profoundly important. ${ }^{25,26}$ Chirality transfer from two catalysts to the product can be particularly complex. Sunoj et al. revealed the origin of high enantioselectivities in a reaction catalysed by axially chiral binaphthyl and cinchona units through transition-state modelling. ${ }^{26}$ Besides applying theoretical studies, it can be proved experimentally if stereodivergence could be achieved by inverting the configuration of the chiral catalysts that are involved in the activation of the reactants.

Herein we report the synthesis of new binaphthyl-cinchona squaramides and their thio analogues, which are good multiple hydrogen bond donor organocatalysts, and the comparison of their application in asymmetric Michael addition of pentane2,4 -dione to trans- $\beta$-nitrostyrene, in asymmetric conjugate addition reaction of lawsone and $\beta, \gamma$-unsaturated $\alpha$-keto ester and, moreover, in aza-Diels-Alder addition reaction of 2-siloxydiene and benzylideneacetone is presented. Furthermore, the effect of the configuration of the axially chiral binaphthyl unit and match-mismatch of chiralities with the cinchona unit was studied.

\section{Results and discussion}

Planning the synthesis of catalysts $\mathbf{1 a}$ and $\mathbf{1 b}$ has begun with a retrosynthetic analysis (Scheme 1). Based on this, a convergent synthetic route starting from commercially available $2,2^{\prime}$-dimethyl1, $\mathbf{1}^{\prime}$-binaphthalene $[(R)-3]$, squaric esters (Sq-M, Sq-B) and cinchona alkaloids (4a and $\mathbf{4 b}$ ) was designed for the preparation of catalysts $\mathbf{1 a}$ and $\mathbf{1 b}$.

Amine fragment $(R)-2$ was prepared through bromination of dimethyl binaphthalene followed by substitution (Scheme 2). The monobromo derivative $(R)-5$ was synthesised using $N$-bromosuccinimide (NBS) as brominating agent and benzoyl peroxide

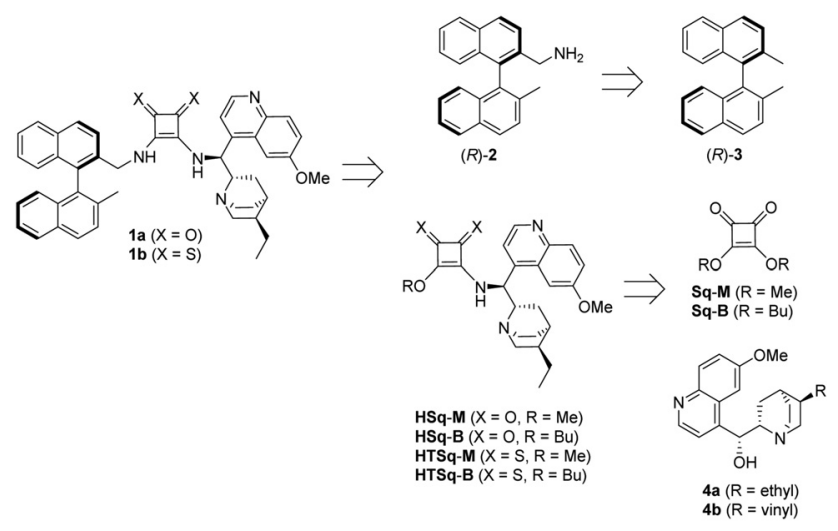

Scheme 1 Retrosynthetic analysis of $\mathbf{1 a}$ and $\mathbf{1 b}$.

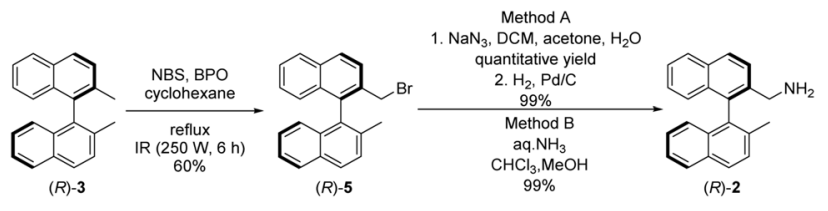

Scheme 2 Synthesis of the axially chiral binaphthalene precursor $(R)-\mathbf{2}$.

(BPO) as initiator. ${ }^{27}$ This product was converted into amine $(R)-2$ in two different ways (Scheme 2): reacting with sodium azide, and reducing the corresponding azide by catalytic hydrogenation (Method A), or applying large excess of aqueous ammonia (Method B). The latter was the preferred procedure, because it is a one-step, easily implemented method providing amine $(R)-2$ with the same yield. Also, in comparison to $\mathrm{Pd} / \mathrm{C}$ and $\mathrm{H}_{2}$; aqueous ammonia solution is an easy to handle reagent.

In our recent publications, ${ }^{28,29}$ we used hydroquinine (4a) as starting material to form its amino derivative $(\mathbf{6}),{ }^{30}$ however quinine (4b) is a cheaper source of the cinchona scaffold. Considering that this method contained a catalytic hydrogenation step, the ethyl derivative 6 was synthesized by reducing the vinyl and the azide group in the same step (Scheme 3). Applying the latter procedure, the intermediates were used without any purification.

The binaphthyl-cinchona squaramide 1a was gained by reacting half-squaramides HSq-M or HSq-B with the aminomethyl binaphthalene $(R)-2$. Application of methyl ester HSq-M as reagent is advantageous due to the higher yield ( $91 \%$ vs. 66\%), and the easier separation of 1a from the excess of HSq-M, than from HSq-B during column chromatography.

The synthesis of binaphthyl-cinchona thiosquaramide $\mathbf{1 b}$ was attempted in many ways (see Scheme 4 and Scheme S1, ESI $\dagger$ ), but it was successful only by thionation of its dioxo form 1a using $\mathrm{P}_{4} \mathrm{~S}_{10}$. pyridine complex. ${ }^{31,32}$ In this synthetic route, the purification of the intermediates is easier than in those that

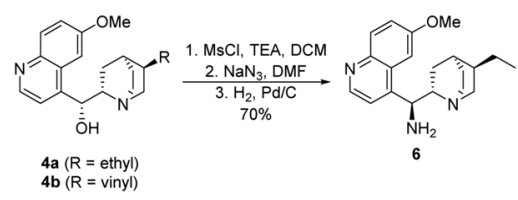

Scheme 3 Synthesis of cinchona amine 6 .

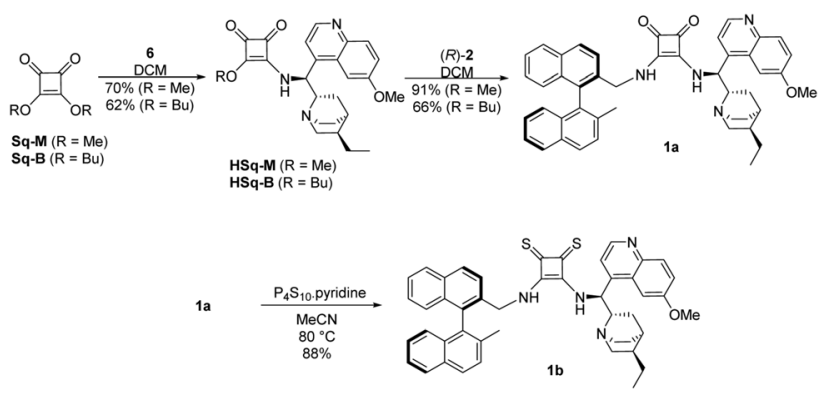

Scheme 4 Synthesis of binaphthyl-cinchona squaramide $1 \mathbf{a}$ and thiosquaramide $\mathbf{1 b}$ organocatalysts. 
Table 1 Test of catalysts $\mathbf{1 a}$ and $\mathbf{1 b}$ in the Michael reaction using trans- $\beta$ nitrostyrene (7) and pentane-2,4-dione $(\mathbf{8})^{a}$

\begin{tabular}{|c|c|c|c|c|}
\hline Entry & Catalyst & Solvent & Yield $^{b}[\%]$ & $\mathrm{ee}^{c}[\%]$ \\
\hline 1 & $1 a$ & DCM & 56 & 95 \\
\hline 2 & 1a & Toluene & 80 & 96 \\
\hline 3 & 1a & EtOAc & 83 & 98 \\
\hline 4 & 1a & MTBE & 70 & 97 \\
\hline 5 & $1 a$ & $\mathrm{MeOH}$ & 52 & 61 \\
\hline 6 & $1 \mathrm{a}$ & $\mathrm{H}_{2} \mathrm{O}$ & 42 & 93 \\
\hline 7 & 1a & Neat & 59 & 98 \\
\hline 8 & 1b & DCM & 44 & 80 \\
\hline 9 & 1b & Toluene & 85 & 96 \\
\hline 10 & 1b & EtOAc & 76 & 98 \\
\hline 11 & 1b & MTBE & 63 & 98 \\
\hline 12 & 1b & $\mathrm{MeOH}$ & 51 & 67 \\
\hline 13 & 1b & $\mathrm{H}_{2} \mathrm{O}$ & 71 & 98 \\
\hline 14 & 1b & Neat & 52 & 100 \\
\hline
\end{tabular}

${ }^{a}$ Reaction conditions: pentane-2,4-dione $(8)(0.41 \mathrm{mmol})$ was added to the solution of trans- $\beta$-nitrostyrene $(7)(0.16 \mathrm{mmol})$ and $5 \mathrm{~mol} \%$ of catalyst $1 \mathbf{a}$ or $\mathbf{1 b}$ in $1 \mathrm{~mL}$ of solvent, then the resulting mixture was stirred at room temperature for 48 hours. ${ }^{b}$ Isolated yields. ${ }^{c}$ Determined by chiral HPLC ( $S$ enantiomer).

apply thionated starting materials or intermediates, due to decomposition of thiosquaramide-derivatives on silica gel. We note here that all compounds were characterised by wellestablished methods including low- and high-resolution MS, IR, 1D and 2D NMR (see Experimental section and ESI†). The binaphthyl-cinchona squaramide 1a was gained by reacting half-squaramides HSq-M or HSq-B with the aminomethyl binaphthalene $(R)-\mathbf{2}$.

The catalytic activity of binaphthyl-cinchona (thio)squaramides $1 \mathbf{a}$ and $\mathbf{1 b}$ was tested in Michael addition reaction using trans- $\beta$-nitrostyrene (7) and pentane-2,4-dione (8) (Table 1).

The highest yields and enantiomeric excesses were reached in ethyl acetate and toluene. Following solvent selection guidelines ${ }^{33-35}$ - based on properties of solvents such as boiling point, health hazard, aquatic and air impact - ethyl acetate was chosen to optimise the amount of catalysts and to decrease the reaction time of the Michael addition reaction from 48 hours to 24 hours. The results are shown in Table 2.

The yields and enantiomeric excesses have not changed significantly by decreasing the reaction time from 48 hours to 24 hours in the presence of $5 \mathrm{~mol} \%$ of catalysts $\mathbf{1 a}$ or $\mathbf{1 b}$. Comparing these two catalysts (1a and $\mathbf{1 b})$, the differences between the yields and enantiomeric excesses were only relevant, when less than $0.5 \mathrm{~mol} \%$ of catalysts were applied. However, in the presence of $0.1 \mathrm{~mol} \%$ catalyst, in both cases, a decrease was noticed in these values, mainly in enantiomeric excesses. No reaction took place in the absence of a catalyst. For thiosquaramide $\mathbf{1 b} 0.2 \mathrm{~mol} \%$ was the minimum catalyst loading, that gave the Michael adduct with high yield and enantiomeric excess, however the ee was only $5 \%$ lower when its dioxo analogue (1a) was used.

The first, preliminary studies of bifunctional aryl thiosquaramides have been reported by Rawal $e t a l .^{22}$ They applied and
Table 2 The optimisation of the amount of catalysts $\mathbf{1 a}$ and $\mathbf{1 b}$ in the Michael reaction using trans- $\beta$-nitrostyrene (7) and pentane-2,4-dione (8) ${ }^{a}$

\begin{tabular}{lllll}
\hline Entry & Catalyst & Amount of catalyst $[\mathrm{mol} \%]$ & $\mathrm{Yield}^{b}[\%]$ & $\mathrm{ee}^{c}[\%]$ \\
\hline 1 & $\mathbf{1 a}$ & 5 & 85 & 98 \\
2 & $\mathbf{1 a}$ & 1 & 93 & 98 \\
3 & $\mathbf{1 a}$ & 0.5 & 93 & 96 \\
4 & $\mathbf{1 a}$ & 0.2 & 90 & 93 \\
5 & $\mathbf{1 a}$ & 0.1 & 88 & 88 \\
6 & $\mathbf{1 b}$ & 5 & 92 & 98 \\
7 & $\mathbf{1 b}$ & 1 & 90 & 97 \\
8 & $\mathbf{1 b}$ & 0.5 & 91 & 98 \\
9 & $\mathbf{1 b}$ & 0.2 & 88 & 77 \\
10 & $\mathbf{1 b}$ & 0.1 & &
\end{tabular}

${ }^{a}$ Reaction conditions: pentane-2,4-dione $(8)(0.41 \mathrm{mmol})$ was added to the solution of trans- $\beta$-nitrostyrene $(7)(0.16 \mathrm{mmol})$ and catalyst $\mathbf{1 a}$ or $\mathbf{1 b}$ in $1 \mathrm{~mL}$ of ethyl acetate, then the reaction mixture was stirred at room temperature for 24 hours. ${ }^{b}$ Isolated yields. ${ }^{c}$ Determined by chiral HPLC ( $S$ enantiomer).

compared oxo- and the corresponding thiosquaramides in the conjugate addition reaction of lawsone (10) to $\beta, \gamma$-unsaturated $\alpha$-keto ester (11), and they achieved $9-22 \%$ higher enantiomeric excesses when thiosquaramides were used, demonstrating the superior performance of this new type of bifunctional catalysts. Also, the higher acidity of aryl thiosquaramides allowed their application as Brønsted acids in aza-Diels-Alder reaction. In this reaction, the corresponding thiourea, oxo-, and thiosquaramides were applied. Product was only afforded, when thiosquaramide was used.

Thus, we applied 1a and $\mathbf{1 b}$ organocatalysts in the aforementioned two asymmetric reactions (Tables 3 and 4).

In the conjugate addition (Table 3), high yields were achieved by the application of catalysts $\mathbf{1 a}$ and $\mathbf{1 b}$, even with $5 \%$ catalyst loading. In all cases, thiosquaramide (1b) gave higher enantioselectivity than its dioxo analogue (1a). These results also prove the noted high catalytic activity of thiosquaramides.

Table 3 The application of catalysts $\mathbf{1 a}$ and $\mathbf{1} \mathbf{b}$ in the conjugate addition of lawsone (10) to $\beta, \gamma$-unsaturated $\alpha$-keto ester $\mathbf{1 1}^{a}$

\begin{tabular}{lllll}
\hline & & & \\
\hline
\end{tabular}

${ }^{a}$ Reaction conditions: $\beta, \gamma$-unsaturated $\alpha$-keto ester (11) $(0.11 \mathrm{mmol})$ was added to the solution of lawsone $(\mathbf{1 0})(0.10 \mathrm{mmol})$ and catalyst $1 \mathrm{a}$ or 1b or DBU in $0.5 \mathrm{~mL}$ of DCM, then stirred at room temperature for 1 hour. ${ }^{b}$ Isolated yields. ${ }^{c}$ Determined by chiral HPLC ( $R$ enantiomer). 
Table 4 The application of catalysts $\mathbf{1 a}$ and $\mathbf{1 b}$ in aza-Diels-Alder reaction of 2 -siloxydiene 13 and $N$-benzylideneaniline (14)

\begin{tabular}{llll}
\hline & Catalyst & $\mathrm{Yield}^{b}[\%]$ & $\mathrm{dr}^{b, c}[\%]$ \\
\hline Entry & 1a & 0 & - \\
\hline 1 & 13 & 80 & $5.4: 1$
\end{tabular}

${ }^{a}$ Reaction conditions: 2-siloxydiene $13(0.20 \mathrm{mmol})$ was added to the solution of $N$-benzylideneaniline (14) $(0.24 \mathrm{mmol})$ and $20 \mathrm{~mol} \%$ of catalyst $1 \mathbf{a}$ or $\mathbf{1 b}$ in $1 \mathrm{~mL}$ of toluene, stirred at room temperature for 12 hours. ${ }^{b}$ Isolated yields. ${ }^{c}$ Determined by ${ }^{1} \mathrm{H}$ NMR.

Following the preliminary studies of Rawal et al., ${ }^{22}$ both organocatalysts (1a and $\mathbf{1 b}$ ) were also applied in aza-Diels-Alder reaction (Table 4). Similarly to their observation, only thiosquaramide (1b) was able to act as Brønsted acid, therefore adduct 15 was only afforded in the reaction when it was catalysed by $\mathbf{1 b}$. Adduct 15 was obtained with $80 \%$ yield in a diastereomeric ratio of 5.4 to 1 (major diastereomer shown in Table 4). Using catalyst 1a, only the unreacted starting materials were detected.

Containing two chiral fragments, namely the cinchona and the binaphthyl unit, $\mathbf{1 a}$ and $\mathbf{1 b}$ could either act as a cooperating (matched pair) or as an uncooperating (mismatched pair) multistereogenic catalyst system. Hence, after the successful utilization of catalysts $\mathbf{1 a}$ and $\mathbf{1} \mathbf{b}$, the application of the "the opposite" catalysts (1c and 1d) synthesised from $(S)-3$, the enantiomer pair of $(R)$-dimethyl binaphthalene $[(R)-3]$, was investigated in the same asymmetric transformations (Scheme 5).

The synthesis of the "opposite" catalysts (1c and 1d) was accomplished by the same route (Scheme S2, ESI $\dagger$ ) as catalysts $\mathbf{1 a}$ and $\mathbf{1 b}$.

First, we tested them in Michael addition reaction using trans- $\beta$-nitrostyrene (7) and pentane-2,4-dione (8) (Table 5).

In this Michael addition 1c and 1d gave the same enantiomer $[(S)]$ of $\mathbf{9}$ in excess as was given by using $\mathbf{1 a}$ and $\mathbf{1 b}$. Comparing oxo-catalysts 1a and 1c, the yields were significantly lower (up to $32 \%$ difference) when 1c was used, in cases of $0.5 \mathrm{~mol} \%$ or lower catalyst loadings, but the enantiomeric excesses have not changed considerably. Notable difference in the efficiency and selectivity between thio-analogues $\mathbf{1 b}$ and $\mathbf{1 d}$ was not noticed. Between 1c and 1d, the yields were up to $27 \%$ higher when thio-squaramide (1d) was used, but the selectivity of these catalysts is comparable.

The conjugate addition of lawsone (10) to $\beta, \gamma$-unsaturated $\alpha$-keto ester (11) proved the noted high catalytic activity of thiosquaramides $^{22}$ (Table 3), therefore we tested the catalysts

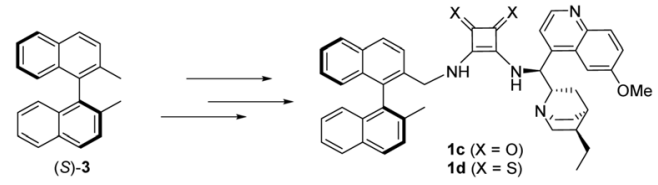

Scheme 5 Synthesis of the opposite catalysts $1 \mathrm{c}$ and $\mathbf{1 d}$.
Table 5 The optimisation of the amount of catalysts $1 \mathrm{c}$ and $1 \mathbf{d}$ in the Michael reaction using trans- $\beta$-nitrostyrene (7) and pentane-2,4-dione $\left(\mathbf{8}^{a}\right.$

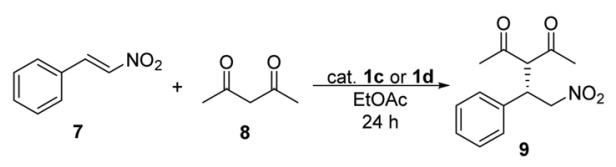

\begin{tabular}{lllll}
\hline Entry & Catalyst & Amount of catalyst $[\mathrm{mol} \%]$ & $\mathrm{Yield}^{b}[\%]$ & $\mathrm{ee}^{c}[\%]$ \\
\hline $\mathbf{1}$ & 1c & 5 & 96 & 96 \\
2 & 1c & 1 & 93 & 94 \\
3 & 1c & 0.5 & 83 & 95 \\
4 & 1c & 0.2 & 62 & 90 \\
5 & 1c & 0.1 & 56 & 81 \\
6 & 1d & 5 & 93 & 98 \\
7 & 1d & 1 & 96 & 97 \\
8 & 1d & 0.5 & 91 & 97 \\
9 & 1d & 0.2 & 86 & 91 \\
10 & 1d & 0.1 & 83 & 84
\end{tabular}

${ }^{a}$ Reaction conditions: pentane-2,4-dione (8) $(0.41 \mathrm{mmol})$ was added to the solution of trans- $\beta$-nitrostyrene $(7)(0.16 \mathrm{mmol})$ and catalyst $1 \mathrm{c}$ or $\mathbf{1 d}$ in $1 \mathrm{~mL}$ of ethyl acetate, then the reaction mixture was stirred at room temperature for 24 hours. ${ }^{b}$ Isolated yields. ${ }^{c}$ Determined by chiral HPLC ( $S$ enantiomer).

Table 6 The application of catalysts $1 \mathbf{c}$ and $\mathbf{1 d}$ in the conjugate addition of lawsone (10) to $\beta, \gamma$-unsaturated $\alpha$-keto ester $\mathbf{1 1}^{\mathrm{a}}$

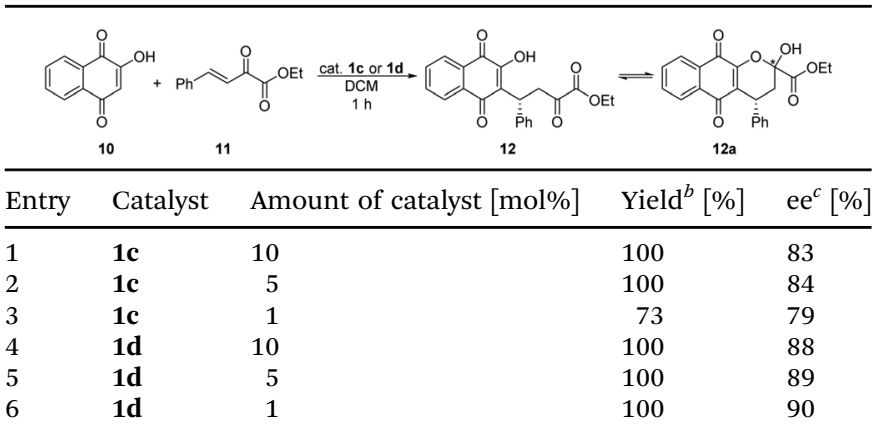

${ }^{a}$ Reaction conditions: $\beta, \gamma$-unsaturated $\alpha$-keto ester $11(0.11 \mathrm{mmol})$ was added to the solution of lawsone $(\mathbf{1 0})(0.10 \mathrm{mmol})$ and catalyst $1 \mathrm{c}$ or $\mathbf{1 d}$ in $0.5 \mathrm{~mL}$ of DCM, stirred at room temperature for 1 hour. ${ }^{b}$ Isolated yields. ${ }^{c}$ Determined by chiral HPLC ( $R$ enantiomer).

1c and 1d in this reaction as well. The results are shown in Table 6. In this conjugate addition, both the yield and selectivity were higher in the presence of only $1 \%$ of thiosquaramide (1d). Comparing these results to the outcomes of conjugate addition catalysed by $\mathbf{1 a}$ and $\mathbf{1 b}$, the same tendency was observed: the enantiomeric excess is approximately $5-10 \%$ higher when thiosquaramide is applied. By applying 1a and 1b or 1c and 1d, the same enantiomer $[(R)]$ of the adduct 12 was obtained.

Finally we tested 1c and 1d catalysts in aza-Diels-Alder reaction, although, none of them gave product; however the reaction has taken place when thiosquaramide $\mathbf{1 b}$ was used. Therefore, the optimisation of the reaction conditions is still in progress.

\section{Theoretical calculations}

The distance between the two NH groups of the squaramide or thiosquaramide unit and the $\mathrm{H}$-bond angle has a significant 
a)

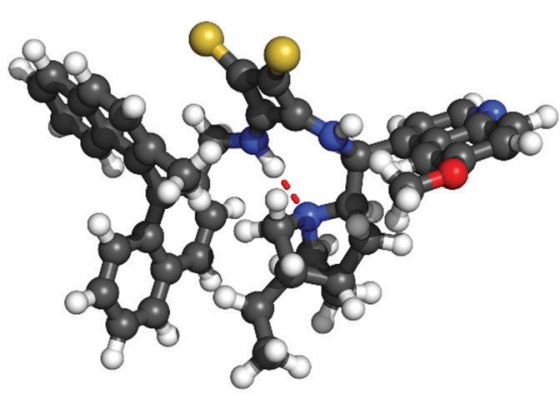

b)

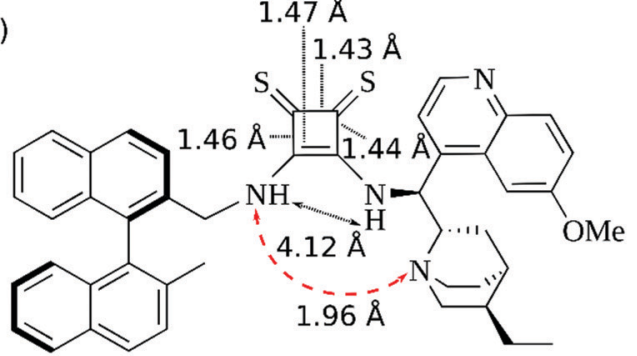

$\mathrm{N}-\mathrm{N}-\mathrm{H}$ angle: $70.3^{\circ}$

S-C-C-S angle: $0.3^{\circ}$

c)

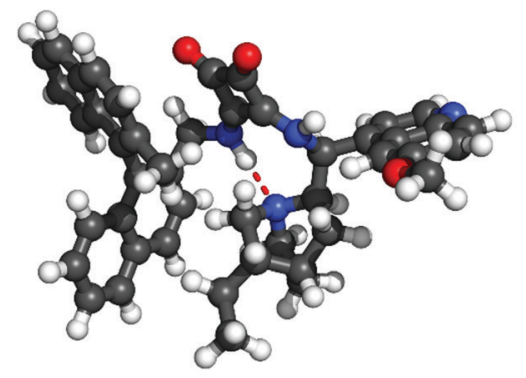

d)

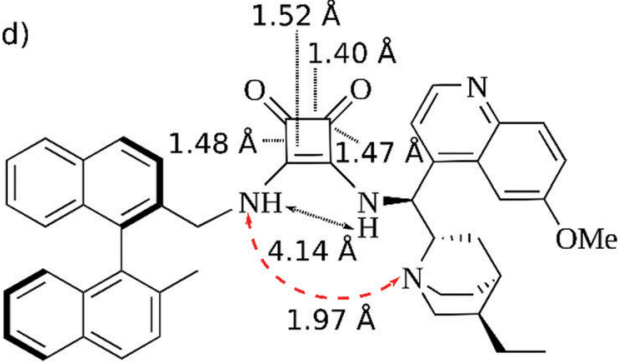

$\mathrm{N}-\mathrm{N}-\mathrm{H}$ angle: $71.4^{\circ}$

O-C-C-O angle: $12.4^{\circ}$

Fig. 2 Optimised geometries and schematic structures of binaphthyl-cinchona thiosquaramide $\mathbf{1 b}$ ( $\mathrm{a}$ and b) and binaphthyl-cinchona squaramide $\mathbf{1 a}$ (c and d) catalysts with the calculated distances and angles. The hydrogen bond between the NH group and the quinuclidine part is shown by red dashed arrows.

effect on the enantioselectivity of the reaction. ${ }^{36,37}$ Therefore, we analysed the differences in the 3D geometric structure of the binaphthyl-cinchona squaramide (1a) and thiosquaramide (1) catalysts (Fig. 2) using quantum chemical calculations.

The calculated distances between the NH groups $(4.12 \AA$ and $4.14 \AA$ ) and also the $\mathrm{N}-\mathrm{N}-\mathrm{H}$ angles $\left(70.3^{\circ}\right.$ and $\left.71.4^{\circ}\right)$ are very similar in both the thiosquaramide and in squaramide catalysts (Fig. 2). Furthermore, a hydrogen bond is formed between the quinuclidine and the squaramide part. Also, only minor differences are observed in the geometry of the four membered rings.

Thus, the molecular geometries of thiosquaramide and squaramide do not imply a significant difference in their enantioselectivities.

\section{Conclusions}

In conclusion, the synthesis of a new class of chiral cinchona (thio)squaramide organocatalysts containing axially chiral binaphthyl moiety was demonstrated. We have addressed a fundamental problem of chiral induction in asymmetric catalysis when two chiral catalytic units act together in a reaction. Cinchona-thiosquaramides (1b and 1d) were first applied as enantioselective organocatalysts in asymmetric Michael addition of pentane-2,4-dione (8) to trans- $\beta$-nitrostyrene (7) performing a thorough solvent screening and parameter optimisation. Compared to their oxo analogues, thiosquaramide catalyst $\mathbf{1 b}$ gave Michael adduct 9 with almost the same yield $(90 \%$ and $91 \%)$ and 1d gave the adduct with significantly higher yield, than its oxo analogue ( $86 \%$ vs. $62 \%)$. Thiosquaramide 1 b gave slightly higher enantioselectivity ( $98 \%$ ee $v s .93 \%$ ee) with even
$0.2 \%$ of catalyst loading in ethyl acetate. In the conjugate addition reaction of lawsone (10) to $\beta, \gamma$-unsaturated $\alpha$-keto ester 11, the adduct 12 was gained with high yields (up to $100 \%$ ), even when $1 \%$ of catalyst loading was applied. In this conjugate addition, the application of $\mathbf{1 b}$ and $\mathbf{1 d}$ thio derivatives resulted in up to $12 \%$ higher enantioselectivities (up to $92 \%$ ) than by using the corresponding oxosquaramides $1 \mathrm{a}$ or $1 \mathrm{c}$. Our results demonstrated clearly that there is no considerable effect of the match-mismatch pair of $(R)$ - and (S)-binaphthyl cinchona (thio)squaramide diastereomers (1a vs. 1c and $\mathbf{1 b}$ vs. 1d) on the selectivity. The Brønsted acid activity of the squaramides and their thio analogues were tested in aza-Diels-Alder addition of 2-siloxydiene 13 to $N$-benzylideneaniline (14). In this reaction the adduct (15) was only obtained when thiosquaramide $\mathbf{1 b}$ was used, with dr of 5.4 (trans):1 (cis). Quantum chemical computations showed that the geometric structures of binaphthyl-cinchona thiosquaramide and squaramide are similar, in line with the experimentally observed similar yield and ee values. These findings significantly expand the scope of applications of thiosquaramide derivatives in asymmetric syntheses.

\section{Experimental}

\section{General}

Infrared spectra were recorded on a Bruker Alpha-T FT-IR spectrometer. Optical rotations were measured on a PerkinElmer 241 polarimeter that was calibrated by measuring the optical rotations of both enantiomers of menthol. NMR spectra were recorded at Directorate of Drug Substance Development, Egis Pharmaceuticals Plc., on a Bruker Avance III HD (at $600 \mathrm{MHz}$ for 
${ }^{1} \mathrm{H}$ and at $150 \mathrm{MHz}$ for ${ }^{13} \mathrm{C}$ spectra) or at Department of Inorganic \& Analytical Chemistry, Budapest University of Technology and Economics, on a Bruker DRX-500 Avance spectrometer (at $500 \mathrm{MHz}$ for ${ }^{1} \mathrm{H}$ and at $125 \mathrm{MHz}$ for ${ }^{13} \mathrm{C}$ spectra) or on a Bruker 300 Avance spectrometer (at $300 \mathrm{MHz}$ for ${ }^{1} \mathrm{H}$ and at $75 \mathrm{MHz}$ for ${ }^{13} \mathrm{C}$ spectra) at temperatures given. Mass spectra were recorded on CAMAG LCMS Interface (HPLC pump: Shimadzu LC-20AD Prominence SQ MS: Shimadzu LCMS-2020 MS settings: detector voltage: $1.10 \mathrm{kV}, \mathrm{m} / \mathrm{z}: 105-1000$, scan speed: $1075 \mu \mathrm{s}^{-1}$, DL temperature: $250{ }^{\circ} \mathrm{C}$, nebulizing gas flow: $1.5 \mathrm{~L} \mathrm{~min}^{-1}$, drying gas flow: $15 \mathrm{~L} \mathrm{~min}^{-1}$. Eluent: acetonitrile: $0.1 \%(\mathrm{v} / \mathrm{v})$ formic acid 95:5, $1.5 \mathrm{~mL} \min ^{-1}$ ). The exact mass measurements were performed using Q-TOF Premier mass spectrometer (Waters Corporation, 34 Maple St, Milford, MA, USA) in positive electrospray ionisation mode. The enantiomeric ratios of the samples were determined by chiral high-performance liquid chromatography (HPLC) measurements using reversed phase mode (Thermo Finnigan Surveyor LC System). Elemental analyses were performed in the Microanalytical Laboratory of the Department of Organic Chemistry, Institute for Chemistry, Eötvös Loránd University, Budapest, Hungary. Melting points were taken on a Boetius micro-melting point apparatus and they were uncorrected. Starting materials were purchased from Aldrich Chemical Company unless otherwise noted. Silica gel $60 \mathrm{~F}_{254}$ (Merck) plates and aluminium oxide $60 \mathrm{~F}_{254}$ (Merck) were used for TLC. The spots of materials on TLC plates were visualised by UV light at $254 \mathrm{~nm}$. Silica gel 60 (70-230 mesh, Merck) was used for column chromatography. Silica gel 60 with particle size of $0.063 \mathrm{~mm}$ was used for dry column vacuum chromatography (DCVC). ${ }^{38}$ Ratios of solvents for the eluents are given in milliliters. PerkinElmer TGA 6 was used to determine the thermal stability of the catalysts with nitrogen purging. The beginning of thermal degradation was determined at $95 \%(\mathrm{w} / \mathrm{w})$ of the measured sample. A $10{ }^{\circ} \mathrm{C} \mathrm{min} \mathrm{m}^{-1}$ heating rate was used from 30 to $700{ }^{\circ} \mathrm{C}$, then the sample was kept at $700{ }^{\circ} \mathrm{C}$ for $10 \mathrm{~min}$. PerkinElmer DSC 7 was used to measure melting point of the catalysts with nitrogen purging.

The computations were carried out using density functional theory applying the $\omega \mathrm{B} 97 \mathrm{X}-\mathrm{D}$ functional ${ }^{39}$ and $6-31 \mathrm{G}^{*}$ basis set, ${ }^{40}$ as it is implemented in the Q-Chem 5.2. quantum chemical software package. ${ }^{41}$ This functional includes long range and dispersion corrections and the accuracy of this method has been tested for similar systems in our previous studies. ${ }^{29,42,43}$ The (75 302) integration grid was applied in all cases. The geometries of the catalysts were optimised both in the gas phase and in ethyl acetate solvent using SM8 continuum solvation method. ${ }^{44}$ Molecules were visualised using the PyMol program. ${ }^{45}$

General procedure for the preparation of 2-(bromomethyl)$2^{\prime}$-methyl-1,1'-binaphthalenes, and their by-products $2,2^{\prime}$-bis(bromomethyl)-1,1'-binaphthalenes. A stirred mixture of 2,2'-dimethyl-1,1'-binaphthalene $[(R)-3$ or $(S)-3] \quad(500 \mathrm{mg}$, $1.77 \mathrm{mmol}), N$-bromosuccinimide $(334 \mathrm{mg}, 1.86 \mathrm{mmol})$ and BPO (22 mg, $0.09 \mathrm{mmol}$ ) were heated at reflux temperature in cyclohexane $(13 \mathrm{~mL})$ with irradiation of infrared light (250 Watt) for $6 \mathrm{~h}$. After the reaction was completed, the solvent was removed under reduced pressure. The crude product was purified by dry column vacuum chromatography ${ }^{38}(4 \mathrm{~mL}$ of hexane was passed through a silica pad with $2 \mathrm{~cm}$ of diameter and $7 \mathrm{~cm}$ of height) to afford mono-, and dibrominated products.

(R)-2-(Bromomethyl)-2'-methyl-1,1'-binaphthalene [(R)-5]. White waxy oil (383 mg, 60\%). TLC $\left(\mathrm{SiO}_{2}\right.$; hexane: DCM = 2:1, $\left.R_{\mathrm{f}}=0.67\right) .[\alpha]_{20}^{\mathrm{D}}+121.2\left(\mathrm{c} 1.00, \mathrm{CHCl}_{3}\right.$ ); IR $\nu_{\max } 3046,1506$, $1212,812,751 \mathrm{~cm}^{-1}$; ${ }^{1} \mathrm{H}$ NMR $\delta$ (ppm, $\left.300 \mathrm{MHz}, \mathrm{DMSO}^{\mathrm{d}}{ }_{6}, 25{ }^{\circ} \mathrm{C}\right)$ $1.96(3 \mathrm{H}, \mathrm{s}), 4.04\left(1 \mathrm{H}, \mathrm{d}, J_{\mathrm{H}, \mathrm{H}} 14.0 \mathrm{~Hz}\right), 4.13(1 \mathrm{H}, \mathrm{d}$, $\left.J_{\mathrm{H}, \mathrm{H}} 14.0 \mathrm{~Hz}\right), 6.85\left(1 \mathrm{H}, \mathrm{d}, J_{\mathrm{H}, \mathrm{H}} 8.5 \mathrm{~Hz}\right), 6.86\left(1 \mathrm{H}, \mathrm{d}, J_{\mathrm{H}, \mathrm{H}} 8.3\right.$ $\mathrm{Hz}), 7.23$ (1 H, overlapped), 7.26 (1 H, overlapped), $7.42(1 \mathrm{H}$, overlapped), 7.45 (1 H, overlapped), $7.58\left(1 \mathrm{H}, \mathrm{d}, J_{\mathrm{H}, \mathrm{H}} 8.4 \mathrm{~Hz}\right), 7.90$ ( $1 \mathrm{H}, \mathrm{d}, J_{\mathrm{H}, \mathrm{H}} 8.6 \mathrm{~Hz}$ ), 7.97 ( $2 \mathrm{H}$, overlapped), 8.00 ( $1 \mathrm{H}$, overlapped), $8.07\left(1 \mathrm{H}, \mathrm{d}, J_{\mathrm{H}, \mathrm{H}} 8.5 \mathrm{~Hz}\right) ;{ }^{13} \mathrm{C}$ NMR $\delta$ (ppm, $75 \mathrm{MHz}, \mathrm{DMSO}_{6}$, $\left.25{ }^{\circ} \mathrm{C}\right) 19.8$, 60.6, 124.8, 125.0, 125.0, 125.4, 126.3, 127.6, 127.7, 128.0, 128.2, 128.7, 131.6, 131.8, 132.1, 132.4, 132.4, 133.2, 134.0, 138.0; MS-ESI $^{+}(\mathrm{m} / \mathrm{z})$ : the ionization was not feasible of this compound under the circumstances of the applied methods (ESI $\mathrm{H}^{+}$addition or $\mathrm{Na}^{+}$addition). Anal. calc. for $\mathrm{C}_{22} \mathrm{H}_{17} \mathrm{Br}(\%)$ : C, 73.14; H, 4.74; Br, 22.12. Found: C, 73.11; H, 4.77; Br, 22.09.

To the best of our knowledge the synthesis of $(R)-5$ has not been reported.

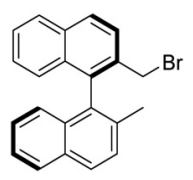

(S)-2-(Bromomethyl)-2'-methyl-1,1'-binaphthalene [(S)-5]. White waxy oil (396 mg, 62\%). $[\alpha]_{20}^{\mathrm{D}}-121.2$ (c 1.00, $\left.\mathrm{CHCl}_{3}\right)$, the other spectroscopic data of this product are the same as those of $(R)-5$.

To the best of our knowledge the synthesis of $(S)-5$ has not been reported.

(R)-2,2'-Bis(bromomethyl)-1,1'-binaphthalene [(R)-5b] (the by-product of the preparation of (R)-5). White crystals $(157 \mathrm{mg}$, $20 \%)$. TLC $\left(\mathrm{SiO}_{2}\right.$; hexane: $\left.\mathrm{DCM}=2: 1, R_{\mathrm{f}}=0.74\right)$. M.p. $161-165{ }^{\circ} \mathrm{C}$. $[\alpha]_{20}^{\mathrm{D}}+161.9\left(\mathrm{c} 1.00, \mathrm{CHCl}_{3}\right.$ ); IR $\nu_{\max } 3048,3010,2966,2917,2849$, 1912, 1773, 1719, 1507, 1463, 1212, 1025, 821, 756, 722, $686 \mathrm{~cm}^{-1}$;

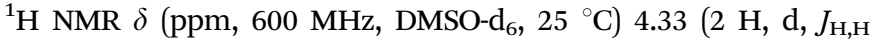
$10.0 \mathrm{~Hz}), 4.37\left(2 \mathrm{H}, \mathrm{d}, J_{\mathrm{H}, \mathrm{H}} 10.0 \mathrm{~Hz}\right), 6.89\left(2 \mathrm{H}, \mathrm{d}, J_{\mathrm{H}, \mathrm{H}} 8.6 \mathrm{~Hz}\right), 7.33$ $\left(2 \mathrm{H}, t, J_{\mathrm{H}, \mathrm{H}} 7.5 \mathrm{~Hz}\right), 7.55\left(2 \mathrm{H}, t, J_{\mathrm{H}, \mathrm{H}} 7.5 \mathrm{~Hz}\right), 7.84\left(2 \mathrm{H}, \mathrm{d}, J_{\mathrm{H}, \mathrm{H}} 8.6\right.$ $\mathrm{Hz}), 8.06\left(2 \mathrm{H}, \mathrm{d}, J_{\mathrm{H}, \mathrm{H}} 8.3 \mathrm{~Hz}\right), 8.17\left(2 \mathrm{H}, \mathrm{d}, J_{\mathrm{H}, \mathrm{H}} 8.6 \mathrm{~Hz}\right) ;{ }^{13} \mathrm{C} \mathrm{NMR}$

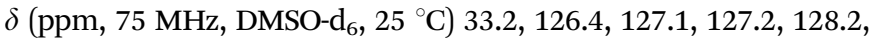
$128.4,129.5,132.0,133.1,133.8,134.2$ MS-ESI $^{+}(\mathrm{m} / \mathrm{z})$ : the ionization was not feasible of this compound under the circumstances of the applied methods (ESI $\mathrm{H}^{+}$addition or $\mathrm{Na}^{+}$addition).

To the best of our knowledge the NMR assignment of $(R)-\mathbf{5 b}$ has not been reported.

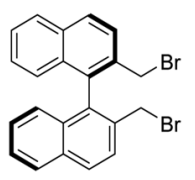

(S)-2,2'-Bis(bromomethyl)-1,1'-binaphthalene [(S)-5b] (the by-product of the preparation of (S)-5). White crystals (151 mg, 19\%). 
M.p. $161-165{ }^{\circ} \mathrm{C} .[\alpha]_{20}^{\mathrm{D}}-161.9\left(\mathrm{c} 1.00, \mathrm{CHCl}_{3}\right)$, the other spectroscopic data of this product are the same as those of $(R)-5 \mathbf{b}$.

To the best of our knowledge the NMR assignment of $(S)-5 \mathbf{b}$ has not been reported.

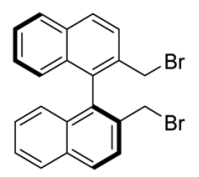

(R)-2-(Azidomethyl)-2'-methyl-1,1'-binaphthalene [(R)-16]. $(R)$-2-Bromomethyl-2'-methyl-1,1'-binaphthalene $[(R)-5](200 \mathrm{mg}$, $0.556 \mathrm{mmol})$, was dissolved in DCM $(1 \mathrm{~mL})$, then acetone $(4 \mathrm{~mL})$, sodium azide $(72.2 \mathrm{mg}, 1.11 \mathrm{mmol})$ and water $(10 \mu \mathrm{L})$ was added. The mixture was stirred until the reaction was completed. The acetone was removed under reduced pressure, and the remaining material was dissolved in a mixture of DCM and water $(2 \mathrm{~mL}$ of each). The phases were shaken well and separated. The organic phase was dried over anhydrous $\mathrm{MgSO}_{4}$ and the solvent was removed under reduced pressure. Further purification was not necessary to afford the pure product as white waxy oil $(179 \mathrm{mg}$, quantitative yield). TLC ( $\mathrm{SiO}_{2}$ TLC; hexane : $\left.\mathrm{DCM}=2: 1, R_{\mathrm{f}}=0.49\right)$. $[\alpha]_{20}^{\mathrm{D}}+60.5$ (c 1.00, $\mathrm{CHCl}_{3}$ ); IR $\nu_{\max } 3053,3010,2918,2805,2090$, 810, $742 \mathrm{~cm}^{-1} ;{ }^{1} \mathrm{H}$ NMR $\delta$ (ppm, $300 \mathrm{MHz}$, DMSO-d $\left.6,25{ }^{\circ} \mathrm{C}\right) 1.99$ $(3 \mathrm{H}, \mathrm{s}), 4.07\left(1 \mathrm{H}, \mathrm{d}, J_{\mathrm{H}, \mathrm{H}} 13.5 \mathrm{~Hz}\right), 4.12\left(1 \mathrm{H}, \mathrm{d}, J_{\mathrm{H}, \mathrm{H}} 13.6 \mathrm{~Hz}\right), 6.83$ $\left(1 \mathrm{H}, \mathrm{d}, J_{\mathrm{H}, \mathrm{H}} 8.4 \mathrm{~Hz}\right), 6.92\left(1 \mathrm{H}, \mathrm{d}, J_{\mathrm{H}, \mathrm{H}} 8.5 \mathrm{~Hz}\right), 7.25\left(1 \mathrm{H}, \mathrm{ddd}, J_{1, \mathrm{H}, \mathrm{H}}\right.$ $\left.8.4 \mathrm{~Hz}, J_{2, \mathrm{H}, \mathrm{H}} 6.9 \mathrm{~Hz}, J_{3, \mathrm{H}, \mathrm{H}} 1.4 \mathrm{~Hz}\right), 7.31\left(1 \mathrm{H}\right.$, ddd, $J_{1, \mathrm{H}, \mathrm{H}} 8.5 \mathrm{~Hz}$, $\left.J_{2, \mathrm{H}, \mathrm{H}} 6.9 \mathrm{~Hz}, J_{3, \mathrm{H}, \mathrm{H}} 1.3 \mathrm{~Hz}\right), 7.44\left(1 \mathrm{H}\right.$, ddd, $J_{1, \mathrm{H}, \mathrm{H}} 8.2 \mathrm{~Hz}, J_{2, \mathrm{H}, \mathrm{H}} 6.9$ $\mathrm{Hz}, J_{3, \mathrm{H}, \mathrm{H}} 1.4 \mathrm{~Hz}$ ), 7.525 ( $1 \mathrm{H}, \mathrm{ddd}, J_{1, \mathrm{H}, \mathrm{H}} 8.2 \mathrm{~Hz}, J_{2, \mathrm{H}, \mathrm{H}} 6.9 \mathrm{~Hz}, J_{3, \mathrm{H}, \mathrm{H}}$ $1.3 \mathrm{~Hz}), 7.61\left(1 \mathrm{H}, \mathrm{d}, J_{\mathrm{H}, \mathrm{H}} 8.5 \mathrm{~Hz}\right), 7.77\left(1 \mathrm{H}, \mathrm{d}, J_{\mathrm{H}, \mathrm{H}} 8.5 \mathrm{~Hz}\right), 7.99$ (1 H, overlapped), $8.02\left(1 \mathrm{H}\right.$, overlapped), $8.06\left(1 \mathrm{H}, \mathrm{d}, J_{\mathrm{H}, \mathrm{H}} 8.4 \mathrm{~Hz}\right)$, $8.13\left(1 \mathrm{H}, \mathrm{d}, J_{\mathrm{H}, \mathrm{H}} 8.5 \mathrm{~Hz}\right) ;{ }^{13} \mathrm{C}$ NMR $\delta$ (ppm, $125 \mathrm{MHz}, \mathrm{DMSO}_{\mathrm{d}}$, $\left.25{ }^{\circ} \mathrm{C}\right) 19.8,52.1,124.7,125.2,125.3,126.4,126.4,126.8,126.9$, 128.1, 128.1, 128.3, 128.3, 128.6, 131.7, 131.8, 132.3, 132.5, 133.0,

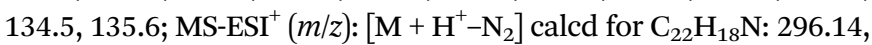
found: 296.20. Anal. calc. for $\mathrm{C}_{22} \mathrm{H}_{17} \mathrm{~N}_{3}$ (\%): C, 81.71; H, 5.30; N, 12.99. Found: C, 81.70; H, 5.33; N, 12.96 .

To the best of our knowledge the synthesis of $(R)-\mathbf{1 6}$ has not been reported.

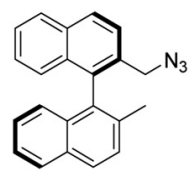

General procedure for the preparation of 2-(aminomethyl)2'-methyl-1,1'-binaphthalenes. Method A: $(R)$-2-azidomethyl-2'methyl-1,1'-binaphthalene $[(R)-16](150 \mathrm{mg}, 0.464 \mathrm{mmol})$, was dissolved in a mixture of DCM $(2 \mathrm{~mL})$ and methanol $(5 \mathrm{~mL})$. $20 \% \mathrm{Pd} / \mathrm{C}$ catalyst $(15 \mathrm{mg})$ was used for the catalytic hydrogenation of the azide $(R)$-16. The hydrogenation was carried out at room temperature in atmospheric pressure using hydrogen gas. The catalyst was filtered through a pad of Celite ${ }^{\circledR}$, then the solvent was removed under reduced pressure. Further purification was not necessary to obtain the pure product as pale-yellow crystals (137 mg, 99\%).
Method B: 2-bromomethyl-2'-methyl-1,1'-binaphthalene $[(R)-5$ or $(S)-5]$ (200 $\mathrm{mg}, 0.556 \mathrm{mmol}$ ), was dissolved in a mixture of chloroform and methanol ( $2 \mathrm{~mL}$ of each), then it was added dropwise to a solution of ammonia ( $4.3 \mathrm{~mL}$ of methanol in $8.6 \mathrm{~mL}$ $25 \%$ aq. $\mathrm{NH}_{3}$ ), and this reaction mixture was stirred for $12 \mathrm{~h}$. After the reaction was completed, the organic solvents were removed under reduced pressure. The remaining aqueous mixture was extracted using chloroform $(5 \mathrm{~mL})$. The organic phase was dried over $\mathrm{MgSO}_{4}$ and the solvent was removed under reduced pressure. Further purification was not necessary to obtain the pure product.

(R)-2-(Aminomethyl)-2'-methyl-1,1'-binaphthalene [(R)-2]. Paleyellow crystals $(165 \mathrm{mg}, 99 \%)$. TLC $\left(\mathrm{SiO}_{2}\right.$ TLC; hexane $: \mathrm{DCM}=$ $\left.2: 1, R_{\mathrm{f}}=0.77\right)$. M.p. $69-71{ }^{\circ} \mathrm{C} ;[\alpha]_{20}^{\mathrm{D}}+12.7\left(\mathrm{c} 0.99, \mathrm{CHCl}_{3}\right)$; IR $\nu_{\max }$ 3371, 3051, 3007, 2917, 2856, 1593, 1506, 812, $744 \mathrm{~cm}^{-1}$; ${ }^{1} \mathrm{H}$ NMR $\delta$ (600 MHz; DMSO-d $\left.)_{6}\right) 1.97$ (3 H, s), $3.28(1 \mathrm{H}, \mathrm{d}$, $\left.J_{\mathrm{H}, \mathrm{H}} 14.8 \mathrm{~Hz}\right), 3.37\left(1 \mathrm{H}, \mathrm{d}, J_{\mathrm{H}, \mathrm{H}} 14.9 \mathrm{~Hz}\right), 6.85\left(1 \mathrm{H}, \mathrm{d}, J_{\mathrm{H}, \mathrm{H}} 8.6\right.$ $\mathrm{Hz}), 6.87\left(1 \mathrm{H}, \mathrm{d}, J_{\mathrm{H}, \mathrm{H}} 8.6 \mathrm{~Hz}\right), 7.24(1 \mathrm{H}$, overlapped), $7.25(1 \mathrm{H}$, overlapped), 7.42 (1 H, overlapped), 7.44 (1 H, overlapped), 7.59 $\left(1 \mathrm{H}, \mathrm{d}, J_{\mathrm{H}, \mathrm{H}} 8.5 \mathrm{~Hz}\right), 7.92\left(1 \mathrm{H}, \mathrm{d}, J_{\mathrm{H}, \mathrm{H}} 8.6 \mathrm{~Hz}\right), 7.97(1 \mathrm{H}$, overlapped), 7.99 (1 H, overlapped), 8.00 (1 H, overlapped), 8.06 $\left(1 \mathrm{H}, \mathrm{d}, J_{\mathrm{H}, \mathrm{H}} 8.6 \mathrm{~Hz}\right) ;{ }^{13} \mathrm{C}$ NMR $\delta$ (ppm, $150 \mathrm{MHz}, \mathrm{DMSO}_{6}$, $\left.25{ }^{\circ} \mathrm{C}\right) 20.1,43.4,125.1,125.1,125.3,125.5,126.3,126.5,126.6$, $127.8,127.9$, 128.3, 128.3, 128.9, 131.9, 132.0, 132.4, 132.5, 133.2, 133.9, 134.3, 139.5; $\mathrm{MS}_{-\mathrm{ESI}^{+}}(\mathrm{m} / \mathrm{z}):\left[\mathrm{M}+\mathrm{H}^{+}\right]$calcd for $\mathrm{C}_{22} \mathrm{H}_{20} \mathrm{~N}$ : 298.16, found: 298.20. Anal. calc. (\%): C, 88.85; H, 6.44; N, 4.71. Found: C, 88.84; H, 6.45; N, 4.71.

To the best of our knowledge the synthesis of $(R)-2$ has not been reported.

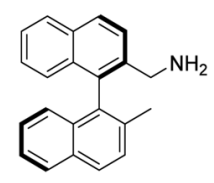

(S)-2-(Aminomethyl)-2'-methyl-1,1'-binaphthalene [(S)-2]. Paleyellow crystals $(165 \mathrm{mg}, 99 \%) .[\alpha]_{20}^{\mathrm{D}}-12.7$ (c $\left.0.99, \mathrm{CHCl}_{3}\right)$, the other spectroscopic data of this product are the same as those of $(R)-2$.

To the best of our knowledge the synthesis of $(S)-2$ has not been reported.

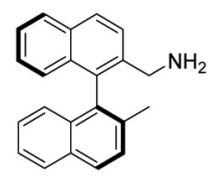

(1S)-[((2S,4S,5R)-5-Ethylquinuclidin-2-yl)(6-methoxyquinolin-4$y l)]$ methanamine (6). This compound was synthesized as described in the literature ${ }^{46}$ with some minor modifications. To a solution of triethylamine (4.1 mL, $2.97 \mathrm{~g}, 29.4 \mathrm{mmol}$ ), and quinine (4b) (2.00 g, $6.2 \mathrm{mmol}$ ) in THF (35 mL) mesyl chloride $(1.9 \mathrm{~mL}, 2.81 \mathrm{~g}$, $24.5 \mathrm{mmol}$ ) was added at $0{ }^{\circ} \mathrm{C}$. The reaction mixture was stirred at room temperature for $4 \mathrm{~h}$. The solvent was removed under reduced pressure, subsequently DCM $(50 \mathrm{~mL})$ and saturated aq. $\mathrm{NaHCO}_{3}$ solution $(50 \mathrm{~mL})$ were added to the residue. The phases 
were shaken well and separated. The organic phase was dried over anhydrous $\mathrm{MgSO}_{4}$ and the solvent was removed. This mesylate intermediate was dissolved in DMF $(50 \mathrm{~mL})$, and sodium azide $(1.6 \mathrm{~g}, 24.7 \mathrm{mmol})$ was added. The reaction mixture was stirred overnight. After the reaction was completed, the solvent was removed under reduced pressure. The crude product was dissolved in methanol $(50 \mathrm{~mL}) .20 \% \mathrm{Pd} / \mathrm{C}$ catalyst (200 mg) was used for the catalytic hydrogenation of the azide intermediate. The hydrogenation was carried out at room temperature in atmospheric pressure using hydrogen gas. After the reaction was completed, the catalyst was filtered through a pad of Celite ${ }^{\mathbb{R}}$, then the solvent was removed under reduced pressure. Further purification was not necessary to obtain the pure product as a yellow oil (1.61 g, 70\% overall yield). Spectral data were fully consistent with those reported in the literature. ${ }^{46}$ TLC $\left(\mathrm{SiO}_{2}\right.$ TLC; DCM : methanol: $\mathrm{NH}_{3}(25 \%$ aq. solution) $\left.=10: 1: 0.01, R_{\mathrm{f}}=0.19\right) .[\alpha]_{20}^{\mathrm{D}}+63.6\left(\mathrm{c} 0.97, \mathrm{CHCl}_{3}\right)$, lit.: $[\alpha]_{20}^{\mathrm{D}}+71.8\left(\mathrm{c} 0.97, \mathrm{CHCl}_{3}\right) ;{ }^{47}$ IR $\nu_{\max } 3371,3299,2926,2859$, 2119, 1918, 1620, 1588, 1506, 1473, 1454, 1431, 1355, 1317, 1259, 1228, 1174, 1133, 1076, 1028, 977, 916, 851, 826, 741, 712, $635 \mathrm{~cm}^{-1}$; ${ }^{1} \mathrm{H}$ NMR $\delta$ (ppm, $\left.500 \mathrm{MHz}, \mathrm{DMSO}_{6}, 80{ }^{\circ} \mathrm{C}\right) 0.71$ $\left(1 \mathrm{H}, \mathrm{dd}, J_{1, \mathrm{H}, \mathrm{H}} 7.6, J_{1, \mathrm{H}, \mathrm{H}} 13.2\right), 0.81\left(3 \mathrm{H}, t, J_{\mathrm{H}, \mathrm{H}} 7.3 \mathrm{~Hz}\right), 1.23$ (1 H, m, overlapped), 1.27 (2 H, m, overlapped), $1.40(1 \mathrm{H}$, $\mathrm{m}$, overlapped), 1.44 (1 H, m, overlapped), 1.52 (1 H, m, overlapped), 1.54 (1 H, m, overlapped), $2.45(1 \mathrm{H}, \mathrm{m}), 2.68(1 \mathrm{H}, \mathrm{m}$, overlapped), 3.00 (1 H, m, overlapped), 3.20 (1 H, m, overlapped), 3.24 (1 H, m, overlapped), $3.96(3 \mathrm{H}, \mathrm{s}), 4.59(1 \mathrm{H}$, $\left.\mathrm{d}, J_{\mathrm{H}, \mathrm{H}} 10.1 \mathrm{~Hz}\right), 7.41\left(1 \mathrm{H}, \mathrm{dd}, J_{1, \mathrm{H}, \mathrm{H}} 2.5, J_{2, \mathrm{H}, \mathrm{H}} 9.2\right), 7.56(1 \mathrm{H}$, $\left.\mathrm{d}, J_{\mathrm{H}, \mathrm{H}} 4.5 \mathrm{~Hz}\right), 7.83(1 \mathrm{H}, \mathrm{s}), 7.95\left(1 \mathrm{H}, \mathrm{d}, J_{\mathrm{H}, \mathrm{H}} 9.2 \mathrm{~Hz}\right), 8.70(1 \mathrm{H}$, $\left.\mathrm{d}, J_{\mathrm{H}, \mathrm{H}} 4.5 \mathrm{~Hz}\right) ;{ }^{13} \mathrm{C}$ NMR $\delta$ (ppm, $125 \mathrm{MHz}$, DMSO-d $6,80{ }^{\circ} \mathrm{C}$ ) 11.4, 24.8, 25.1, 26.6, 28.0, 36.8, 40.1, 52.5, 55.2, 57.1, 60.9, 102.9, 119.9, 120.4, 128.2, 130.8, 143.9, 147.2, 147.4, 156.6; MS-ESI ${ }^{+}(\mathrm{m} / \mathrm{z})$ : $\left[\mathrm{M}+\mathrm{H}^{+}\right]$calcd for $\mathrm{C}_{20} \mathrm{H}_{28} \mathrm{~N}_{3} \mathrm{O}$ : 326.22, found: 326.22.

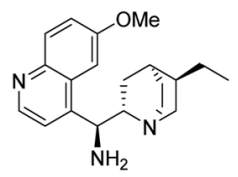

General procedure for the preparation of cinchona halfsquaramides. A solution of cinchona amine 6 (400 mg, $1.23 \mathrm{mmol})$ in DCM $(0.5 \mathrm{~mL})$ was added in three portions to a solution of dimethyl squarate (Sq-M) $(193 \mathrm{mg}, 1.36 \mathrm{mmol})$ or dibutyl squarate (Sq-B) (308 mg, $1.36 \mathrm{mmol}$ ) in DCM $(0.5 \mathrm{~mL})$. This mixture was stirred overnight at room temperature. The solvent was removed under reduced pressure, then the crude product was purified by column chromatography $\left(\mathrm{SiO}_{2} ; \mathrm{DCM}\right.$ : methanol $=10: 1$ ) to obtain HSq-M or HSq-B.

(((1S)-((2S,4S,5R)-5-Ethylquinuclidin-2-yl)(6-methoxyquinolin-4yl)methyl)amino)-4-methoxycyclobut-3-ene-1,2-dione (HSq-M). Paleyellow crystals $(375 \mathrm{mg}, 70 \%)$. TLC $\left(\mathrm{SiO}_{2} \mathrm{TLC}\right.$; DCM: methanol = $10: 1, R_{\mathrm{f}}=0.28$ ). M.p. $120{ }^{\circ} \mathrm{C}$ (decomposed) $[\alpha]_{20}^{\mathrm{D}}-60$ (c 1.00, chloroform); IR $\nu_{\max } 3186,3078,2954,2932,2870,1802,1705$, 1667, 1622, 1606, 1552, 1509, 1475, 1434, 1392, $1224 \mathrm{~cm}^{-1}$;

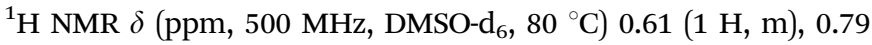

(3 H, t, J $\left.J_{\mathrm{H}, \mathrm{H}} 12.0 \mathrm{~Hz}\right), 1.27$ (2 H, overlapped), 1.31 (1 H, overlapped), 1.41 (1 H, overlapped), 1.43 (1 H, overlapped), $1.53(1 \mathrm{H}$, overlapped), 1.56 (1 H, overlapped), $2.46\left(1 \mathrm{H}, \mathrm{d}, J_{\mathrm{H}, \mathrm{H}} 13.5 \mathrm{~Hz}\right)$, 2.66 ( $1 \mathrm{H}, \mathrm{m}), 3.15$ (1 H, overlapped), 3.19 (1 H, overlapped), 3.39 (1 H, overlapped), 3.95 (3 H, s), 4.25 ( $3 \mathrm{H}, \mathrm{s}), 5.75$ ( $1 \mathrm{H}$, broad), 7.45 $\left(1 \mathrm{H}, \mathrm{d}, J_{\mathrm{H}, \mathrm{H}} 9.0 \mathrm{~Hz}\right), 7.64\left(1 \mathrm{H}, \mathrm{d}, J_{\mathrm{H}, \mathrm{H}} 4.0 \mathrm{~Hz}\right.$, overlapped), 7.66 (1 H, overlapped), $7.97\left(1 \mathrm{H}, \mathrm{d}, J_{\mathrm{H}, \mathrm{H}} 9.0 \mathrm{~Hz}\right), 8.77\left(1 \mathrm{H}, \mathrm{d}, J_{\mathrm{H}, \mathrm{H}}\right.$ $4.0 \mathrm{~Hz}$ ); ${ }^{13} \mathrm{C}$ NMR $\delta$ (ppm, $\left.125 \mathrm{MHz}, \mathrm{DMSO}_{-} \mathrm{d}_{6}, 80{ }^{\circ} \mathrm{C}\right) 12.0,24.8$, 25.6, 27.0, 28.0, 36.7, 40.2, 52.0, 55.6, 57.1, 58.5, 60.1, 101.1, 119.9, 121.9, 127.3, 131.6, 142.9, 144.2, 147.8, 157.9, 170.8, 177.8, 181.4, 189.9; MS-ESI $^{+}(\mathrm{m} / \mathrm{z}):\left[\mathrm{M}+\mathrm{H}^{+}\right]$calcd for $\mathrm{C}_{25} \mathrm{H}_{30} \mathrm{~N}_{3} \mathrm{O}_{4}$ : 436.22, found: 436.30. Anal. calc. (\%): C, 68.95; H, 6.71; N, 9.65. Found: C, 68.92; H, 6.74; N, 9.65.

To the best of our knowledge the synthesis of HSq-M has not been reported.

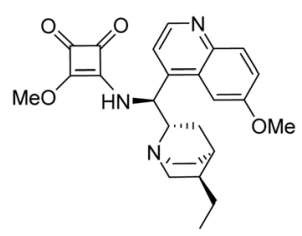

3-(((1S)-((2S,4S,5R)-5-Ethylquinuclidin-2-yl)(6-methoxyquinolin4-yl)methyl)amino)-4-butoxycyclobut-3-ene-1,2-dione (HSq-B). White crystals (287 mg, 62\%). TLC $\left(\mathrm{SiO}_{2}\right.$ TLC; DCM: methanol = 10:1, $R_{\mathrm{f}}=0.38$ ). M.p. $120{ }^{\circ} \mathrm{C}$ (decomposed) $[\alpha]_{20}^{\mathrm{D}}-129$ (c 1.00, chloroform); IR $\nu_{\max } 3234,3075,3034,2956,2932,2870,1802$, 1706, 1606, 1509, 1475, 1433, 1359, 1297, 1259, 1229, 1171, 1084, 1029, 919, $853 \mathrm{~cm}^{-1}$; ${ }^{1} \mathrm{H}$ NMR $\delta\left(600 \mathrm{MHz}\right.$; DMSO-d $\left.6,60{ }^{\circ} \mathrm{C}\right) 0.80\left(3 \mathrm{H}, t, J_{\mathrm{H}, \mathrm{H}} 7.4\right), 0.85$ (3 H, overlapped), 1.29 ( $2 \mathrm{H}$, broad), 1.33 (2 H, overlapped), 1.39 (1 H, overlapped), 1.42 (1 H, overlapped), 1.52 (1 H, overlapped), 1.54 (1 H, overlapped), 1.67 (1 H, broad), 2.43 (1 H, broad), $2.64(1 \mathrm{H}$, broad), 3.14 (1 H, overlapped), 3.17 (1 H, overlapped), $3.35(1 \mathrm{H}$, broad), 3.96 (3 H, s), 4.56 (2 H, broad), $7.46\left(1 \mathrm{H}, \mathrm{d}, J_{\mathrm{H}, \mathrm{H}} 9.1\right), 7.63$ $\left(1 \mathrm{H}, \mathrm{d}, J_{\mathrm{H}, \mathrm{H}} 4.5 \mathrm{~Hz}\right.$, overlapped), $7.72(1 \mathrm{H}$, broad $), 7.98\left(1 \mathrm{H}, \mathrm{d}, J_{\mathrm{H}, \mathrm{H}}\right.$ 9.1), $8.77\left(1 \mathrm{H}, \mathrm{d}, J_{\mathrm{H}, \mathrm{H}} 4.5\right), 9.02\left(1 \mathrm{H}\right.$, broad); ${ }^{13} \mathrm{C}$ NMR $\delta(150 \mathrm{MHz}$; DMSO-d $\left.{ }_{6}, 60{ }^{\circ} \mathrm{C}\right) 11.8,13.2,17.9,24.9,25.5,26.9,28.1,31.3,36.9$, 40.3, 53.3, 55.6, 57.0, 58.7, 72.6, 101.1, 120.1, 121.4, 127.4, 131.5, 143.2, 144.2, 147.7, 157.8, 171.2, 177.3, 181.6, 189.5; MS-ESI ${ }^{+}(\mathrm{m} / \mathrm{z})$ : $\left[\mathrm{M}+\mathrm{H}^{+}\right]$calcd for $\mathrm{C}_{28} \mathrm{H}_{36} \mathrm{~N}_{3} \mathrm{O}_{4}$ : 478.27, found: 478.30. Anal. calc. (\%): C, 70.42; H, 7.39; N, 8.80. Found: C, 70.40; H, 7.40; N, 8.79.

To the best of our knowledge the synthesis of HSq-B has not been reported.

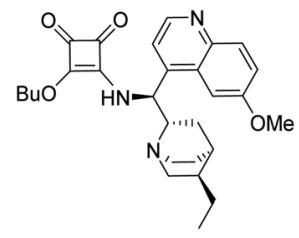

General procedures for the preparation of binaphthyl cinchonaoxosquaramides. A solution of aminomethyl binaphthalene $[(R)-2$ or $(S)-2]$ (200 $\mathrm{mg}, 0.67 \mathrm{mmol})$ in chloroform $(0.7 \mathrm{~mL})$ was added to a solution of cinchona half squaramide (HSq-M: $322 \mathrm{mg}, 0.74 \mathrm{mmol}$ or HSq-B: $353 \mathrm{mg}, 0.74 \mathrm{mmol})$ in chloroform $(1.5 \mathrm{~mL})$. This mixture 
was stirred for $5 \mathrm{~h}$ at room temperature. The solvent was removed under reduced pressure, then the crude product was purified by column chromatography on silica gel using DCM: methanol: $\mathrm{NH}_{3}$ $(40: 1: 0.01)$ mixture as an eluent to obtain the pure product.

3-(((1S)-((2S,4S,5R)-5-Ethylquinuclidin-2-yl)(6-methoxyquinolin4-yl)methyl)amino)-4-(R)-(((2'-methyl-[1,1'-binaphthalen]-2-yl)methyl)amino)cyclobut-3-ene-1,2-dione (1a). Pale-yellow crystals $(427 \mathrm{mg}$, 91\% with reagent $\mathbf{H S q}-\mathbf{M}$ and $310 \mathrm{mg}, 66 \%$ with reagent $\mathbf{H S q}-\mathbf{B})$. M.p. $170{ }^{\circ} \mathrm{C}$ (DSC), TLC ( $\mathrm{SiO}_{2}$ TLC; DCM: methanol: $\mathrm{NH}_{3}=$ $\left.40: 1: 0.01, R_{\mathrm{f}}=0.31\right) .[\alpha]_{20}^{\mathrm{D}}-44,7$ (c 1.00, $\mathrm{CHCl}_{3}$ ); IR $\nu_{\max }$ 3234, 3051, 3004, 2930, 2860, 1794, 1676, 1621, 2589, 1530, 1508, 1458, 1359, 1260, 1241, $1224 \mathrm{~cm}^{-1}$; ${ }^{1} \mathrm{H}$ NMR $\delta(\mathrm{ppm}$, $\left.500 \mathrm{MHz}, \mathrm{DMSO}_{6}, 60{ }^{\circ} \mathrm{C}\right) 0.70(1 \mathrm{H}, \mathrm{m}), 0.81\left(3 \mathrm{H}, t, J_{\mathrm{H}, \mathrm{H}}\right.$ $7.4 \mathrm{~Hz}$ ), 1.36 (2 H, overlapped), 1.53 (1 H, overlapped), $1.54(2 \mathrm{H}$, overlapped), 1.64 (1 H, overlapped), 1.65 (1 H, overlapped), 1.75 (3 H, s), 2.57 (1 H, m), 2.77 (1 H, wide), 3.28 (1 H, overlapped), 3.45 (1 H, overlapped), 3.66 (1 H, overlapped), 3.96 (3 H, s), 4.31 $\left(1 \mathrm{H}, \mathrm{dd}, J_{1, \mathrm{H}, \mathrm{H}} 5.2 \mathrm{~Hz}, J_{2, \mathrm{H}, \mathrm{H}} 14.9 \mathrm{~Hz}\right), 4.40\left(1 \mathrm{H}, \mathrm{dd}, J_{1, \mathrm{H}, \mathrm{H}}\right.$ $6.8 \mathrm{~Hz}, J_{2, \mathrm{H}, \mathrm{H}} 14.9 \mathrm{~Hz}$ ), 5.98 (1 H, wide), 7.19 ( $1 \mathrm{H}$, ddd, $J_{1, \mathrm{H}, \mathrm{H}}$ $1.3 \mathrm{~Hz}, J_{2, \mathrm{H}, \mathrm{H}} 6.7 \mathrm{~Hz}, J_{3, \mathrm{H}, \mathrm{H}} 14.9 \mathrm{~Hz}$ ), 7.26 (2 H, overlapped), 7.37 $\left(1 \mathrm{H}\right.$, ddd, $\left.J_{1, \mathrm{H}, \mathrm{H}} 1.0 \mathrm{~Hz}, J_{2, \mathrm{H}, \mathrm{H}} 6.7 \mathrm{~Hz}, J_{3, \mathrm{H}, \mathrm{H}} 14.9 \mathrm{~Hz}\right), 7.46(1 \mathrm{H}$, overlapped), 7.48 (1 H, overlapped), $7.59\left(1 \mathrm{H}, \mathrm{d}, J_{\mathrm{H}, \mathrm{H}} 4.6 \mathrm{~Hz}\right)$, $7.69\left(1 \mathrm{H}, \mathrm{d}, J_{\mathrm{H}, \mathrm{H}} 8.6 \mathrm{~Hz}\right), 7.78\left(1 \mathrm{H}, \mathrm{d}, J_{\mathrm{H}, \mathrm{H}} 2.7 \mathrm{~Hz}\right), 7.84(1 \mathrm{H}, \mathrm{d}$, $\left.J_{\mathrm{H}, \mathrm{H}} 7.2 \mathrm{~Hz}\right), 7.90\left(1 \mathrm{H}, \mathrm{d}, J_{\mathrm{H}, \mathrm{H}} 8.1 \mathrm{~Hz}\right), 7.99$ (2 H, overlapped), $8.04\left(1 \mathrm{H}, \mathrm{d}, J_{\mathrm{H}, \mathrm{H}} 8.6 \mathrm{~Hz}\right), 8.78\left(1 \mathrm{H}, \mathrm{d}, J_{\mathrm{H}, \mathrm{H}} 4.6 \mathrm{~Hz}\right) ;{ }^{13} \mathrm{C} \mathrm{NMR}$ $\delta\left(\mathrm{ppm}, 125 \mathrm{MHz}, \mathrm{DMSO}^{\left.-\mathrm{d}_{6}, 60{ }^{\circ} \mathrm{C}\right)}\right.$ 11.4, 19.4, 24.5, 25.1, 26.1, 26.7, 35.9, 40.2, 45.1, 53.0, 55.6, 56.5, 58.7, 101.6, 121.6, 124.3, $124.7,124.9,125.8,125.8,126.2,126.5,127.2,127.6,127.8$, $127.9,128.0,128.1,131.3,131.6,131.7,132.0,132.3,132.5$, $133.5,134.0,134.5,144.2$, 147.4, 157.8, 165.9, 167.6, 181.3, 182.2; HRMS-ESI ${ }^{+}(\mathrm{m} / \mathrm{z}):\left[\mathrm{M}+\mathrm{H}^{+}\right]$calcd for $\mathrm{C}_{46} \mathrm{H}_{45} \mathrm{~N}_{4} \mathrm{O}_{3}$ : 701.3492, found: 701.3501.

To the best of our knowledge the synthesis of 1a has not been reported.

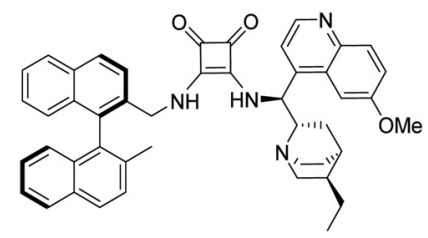

3-(((1S)-((2S,4S,5R)-5-Ethylquinuclidin-2-yl)(6-methoxyquinolin-4$y l) m e t h y l)$ amino $)-4-(S)-\left(\left(\left(2^{\prime}-\right.\right.\right.$ methyl-[1,1'-binaphthalen $\left.\left.]-2-y l\right) m e t h y l\right)-$ amino)cyclobut-3-ene-1,2-dione (1c). Pale-yellow crystals $(413 \mathrm{mg}$, $88 \%$ with reagent HSq-M). M.p. $204-206{ }^{\circ} \mathrm{C}$, TLC $\left(\mathrm{SiO}_{2} \mathrm{TLC}\right.$; DCM : methanol: $\left.\mathrm{NH}_{3}=40: 1: 0.01, R_{\mathrm{f}}=0.29\right) .[\alpha]_{20}^{\mathrm{D}}-76,6$ (c $1.00, \mathrm{CHCl}_{3}$ ); IR $\nu_{\max } 3425,2931,1796,1677,1621,1590$, 1530, 1509, 1460, 1360, 1260, 1242, 1028, 813, $687 \mathrm{~cm}^{-1}$; ${ }^{1} \mathrm{H}$ NMR $\delta\left(\mathrm{ppm}, 400 \mathrm{MHz}, \mathrm{DMSO}_{-} \mathrm{d}_{6}, 117{ }^{\circ} \mathrm{C}\right) 0.76(1 \mathrm{H}, \mathrm{b})$, $0.83\left(3 \mathrm{H}, t, J_{\mathrm{H}, \mathrm{H}} 7.4 \mathrm{~Hz}\right), 1.07\left(2 \mathrm{H}, t, J_{\mathrm{H}, \mathrm{H}} 7 \mathrm{~Hz}\right), 1.37\left(2 \mathrm{H}, \mathrm{q}, J_{\mathrm{H}, \mathrm{H}}\right.$ $8 \mathrm{~Hz}), 1.53$ (1 H, b), 1.65 (1 H, b), 1.69 (1 H, b), 1.94 (3 H, s), 2.67 $(1 \mathrm{H}, \mathrm{b}), 3.76(1 \mathrm{H}, \mathrm{b}), 3.37(1 \mathrm{H}, \mathrm{m}), 3.47\left(2 \mathrm{H}, \mathrm{q}, J_{\mathrm{H}, \mathrm{H}}=7 \mathrm{~Hz}\right)$, $3.94(3 \mathrm{H}, \mathrm{s}), 4.39\left(2 \mathrm{H}, \mathrm{d}, J_{\mathrm{H}, \mathrm{H}}=5.2 \mathrm{~Hz}\right), 5.97\left(1 \mathrm{H}, \mathrm{d}, J_{\mathrm{H}, \mathrm{H}}=\right.$ $10.6 \mathrm{~Hz}), 6.79\left(1 \mathrm{H}, \mathrm{d}, J_{\mathrm{H}, \mathrm{H}}=8.6 \mathrm{~Hz}\right), 6.88\left(1 \mathrm{H}, \mathrm{d}, J_{\mathrm{H}, \mathrm{H}}=8.6 \mathrm{~Hz}\right)$, $6.93\left(1 \mathrm{H}, t, J_{\mathrm{H}, \mathrm{H}} 7 \mathrm{~Hz}\right), 7.04\left(1 \mathrm{H}, t, J_{\mathrm{H}, \mathrm{H}} 7.6 \mathrm{~Hz}\right), 7.23\left(1 \mathrm{H}, t, J_{\mathrm{H}, \mathrm{H}}\right.$ $7.6 \mathrm{~Hz}), 7.44(1 \mathrm{H}, \mathrm{m}), 7.45(1 \mathrm{H}, \mathrm{m}), 7.46(1 \mathrm{H}, \mathrm{m}), 7.54(1 \mathrm{H}, \mathrm{d}$, $\left.J_{\mathrm{H}, \mathrm{H}} 4.6 \mathrm{~Hz}\right), 7.67\left(1 \mathrm{H}, \mathrm{d}, J_{\mathrm{H}, \mathrm{H}} 8.6 \mathrm{~Hz}\right), 7.73(1 \mathrm{H}, \mathrm{m}), 7.74(1 \mathrm{H}$, m), $7.84\left(1 \mathrm{H}, \mathrm{d}, J_{\mathrm{H}, \mathrm{H}} 8.4 \mathrm{~Hz}\right), 7.96(1 \mathrm{H}, \mathrm{m}), 7.98(1 \mathrm{H}, \mathrm{m}), 8.00$ $(1 \mathrm{H}, \mathrm{m}), 8.75\left(1 \mathrm{H}, \mathrm{d}, J_{\mathrm{H}, \mathrm{H}}=4.6 \mathrm{~Hz}\right) ;{ }^{13} \mathrm{C} \mathrm{NMR} \delta(\mathrm{ppm}, 100 \mathrm{MHz}$, DMSO-d $\left._{6}, 117{ }^{\circ} \mathrm{C}\right)$ 10.9, 17.9, 19.2, 24.3, 24.5, 25.7, 35.5, 45.1, 52.9 , 55.5, 55.7, 56.3, 59.3, 101.9, 119.3, 121.4, 124.2, 124.3, $124.8,125.5,125.5,125.6,126.1,127.0,127.3,127.4,127.6$, $127.7,128.1,131.1,131.4,131.6,131.7,132.0,132.3,132.5$, 133.4, 133.8, 134.6, 144.2, 147.2, 157.8, 165.7, 168.0, 181.5, 182.3; HRMS-ESI ${ }^{+}(\mathrm{m} / \mathrm{z}):\left[\mathrm{M}+\mathrm{H}^{+}\right]$calcd for $\mathrm{C}_{46} \mathrm{H}_{45} \mathrm{~N}_{4} \mathrm{O}_{3}$ : 701.3492, found: 701.3501 .

To the best of our knowledge the synthesis of 1c has not been reported.

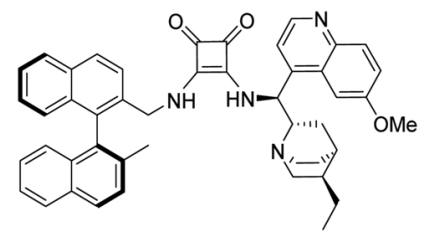

General procedure for the preparation of binaphthyl cinchonathiosquaramides. A solution of binaphthyl-cinchona squaramide (1a or $1 \mathrm{c}, 80 \mathrm{mg}, 0.114 \mathrm{mmol}$ ) in acetonitrile $(1 \mathrm{~mL})$ was added to the pyridine complex of phosphorus pentasulfide $(87 \mathrm{mg}$, $0.228 \mathrm{mmol}$ ). The reaction mixture was stirred at $80{ }^{\circ} \mathrm{C}$ for 4 hours. After the reaction was completed, the mixture was poured onto water $(10 \mathrm{~mL})$, then the precipitated yellow crystals were filtered, and dried on air. The crude product was dissolved in DCM and filtered through a pad of aluminium oxide. The solvent was evaporated, and this crude product was dissolved in DCM $(0.5 \mathrm{~mL})$, and hexane $(5 \mathrm{~mL})$ was added to this solution. The precipitated orange crystals were filtered, washed with hexane and dried under reduced pressure to obtain thiosquaramide catalysts. The product can be used without further purification.

3-(((1S)-((2S,4S,5R)-5-Ethylquinuclidin-2-yl)(6-methoxyquinolin4-yl)methyl)amino)-4-(R)-(((2'-methyl-[1,1'-binaphthalen $]-2-y l) m e t h y l)-$ amino)cyclobut-3-ene-1,2-dithione (1b). Orange crystals $(74 \mathrm{mg}$, $88 \%$ ). TLC (aluminium oxide TLC; chloroform:methanol: $\left.\mathrm{NH}_{3}=40: 1: 0.01\right) R_{\mathrm{f}}=0.69 ;\left(\mathrm{SiO}_{2} \mathrm{TLC} ;\right.$ chloroform $:$ methanol $=$ $\left.40: 1: 0.01 \mathrm{NH}_{3}\right) R_{\mathrm{f}}=0.23$. M.p. $237^{\circ} \mathrm{C}$ (DSC), $[\alpha]_{20}^{\mathrm{D}}-44.6(\mathrm{c} 0.25$, $\mathrm{CHCl}_{3}$ ); IR $\nu_{\max } 3436,3169,3051,2999,2930,2872,1917,1762$, 1698, 1620, 1588, 1507, 1474, 1432, 1357, 1243, 1143, 1085, 1028, 812, $748 \mathrm{~cm}^{-1}$; ${ }^{1} \mathrm{H}$ NMR $\delta$ (ppm, $600 \mathrm{MHz}, \mathrm{DMSO}_{6}$, $\left.60{ }^{\circ} \mathrm{C}\right) 0.74\left(3 \mathrm{H}, t, J_{\mathrm{H}, \mathrm{H}} 7.4 \mathrm{~Hz}\right), 0.94\left(1 \mathrm{H}, \mathrm{m}, J_{\mathrm{H}, \mathrm{H}} 13.0 \mathrm{~Hz}\right), 1.28$ $\left(1 \mathrm{H}, t, J_{\mathrm{H}, \mathrm{H}} 7.4 \mathrm{~Hz}\right), 1.60\left(1 \mathrm{H}, t, J_{\mathrm{H}, \mathrm{H}} 12.0 \mathrm{~Hz}\right), 1.74(3 \mathrm{H}, \mathrm{s}), 1.81$ (1 H, overlapped), 1.83 (3 H, overlapped), 3.09 (1 H, overlapped), 3.12 (1 H, overlapped), 3.57 (1 H, wide), $4.03(1 \mathrm{H}, \mathrm{s})$, 4.12 (1 H, overlapped), 4.43 (1 H, wide), 4.76 (3 H, d, $J_{\mathrm{H}, \mathrm{H}} 15.4$ $\mathrm{Hz}), 5.16\left(1 \mathrm{H}, \mathrm{d}, J_{\mathrm{H}, \mathrm{H}} 15.4 \mathrm{~Hz}\right), 6.84\left(2 \mathrm{H}, \mathrm{d}, J_{\mathrm{H}, \mathrm{H}} 8.4 \mathrm{~Hz}\right), 7.16$ ( $1 \mathrm{H}$, wide), 7.20 ( $2 \mathrm{H}$, overlapped), $7.24\left(1 \mathrm{H}, t, J_{\mathrm{H}, \mathrm{H}} 7.6 \mathrm{~Hz}\right), 7.35$ $\left(1 \mathrm{H}, t, J_{\mathrm{H}, \mathrm{H}} 7.2 \mathrm{~Hz}\right), 7.45\left(1 \mathrm{H}, t, J_{\mathrm{H}, \mathrm{H}} 7.1 \mathrm{~Hz}\right), 7.49(1 \mathrm{H}$, dd, $\left.J_{1, \mathrm{H}, \mathrm{H}} 2.7 \mathrm{~Hz}, J_{2, \mathrm{H}, \mathrm{H}} 9.2 \mathrm{~Hz}\right), 7.82\left(1 \mathrm{H}, \mathrm{d}, J_{\mathrm{H}, \mathrm{H}} 8.4 \mathrm{~Hz}\right), 7.85(1 \mathrm{H}$, overlapped), 7.86 (1 H, overlapped), 7.92 (1 H, wide), $7.97(1 \mathrm{H}$, $\mathrm{d}, J_{\mathrm{H}, \mathrm{H}} 8.3 \mathrm{~Hz}$ ), 8.00 (1 H, overlapped), 8.02 (1 H, overlapped), 
$8.04\left(1 \mathrm{H}, \mathrm{d}, J_{\mathrm{H}, \mathrm{H}} 8.7 \mathrm{~Hz}\right), 8.86\left(1 \mathrm{H}, \mathrm{d}, J_{\mathrm{H}, \mathrm{H}} 4.6 \mathrm{~Hz}\right) ;{ }^{13} \mathrm{C} \mathrm{NMR} \delta$ (ppm, $150 \mathrm{MHz}, \mathrm{DMSO}_{6}, 60{ }^{\circ} \mathrm{C}$ ) 11.2, 19.8, 23.3, 23.9, 24.5, 25.2, 34.5, 41.2, 44.9, 51.8, 55.2, 56.3, 59.8, 102.2, 120.7, 122.4, $124.6,124.9,124.9,125.7,125.9,126.4,126.6,126.6,127.9$, $128.0,128.1,128.2,128.3,131.7,131.8,131.9,132.1,132.3$, $132.6,132.7,134.2,134.4,141.1,144.4,147.8,158.2,169.6$, 170.9, 202.4, 204.9; HRMS-ESI ${ }^{+}(\mathrm{m} / \mathrm{z}):\left[\mathrm{M}+\mathrm{H}^{+}\right]$calcd for $\mathrm{C}_{46} \mathrm{H}_{45} \mathrm{~N}_{4} \mathrm{~S}_{2} \mathrm{O}: 733.3035$, found: 733.3043 .

To the best of our knowledge the synthesis of $\mathbf{1 b}$ has not been reported.

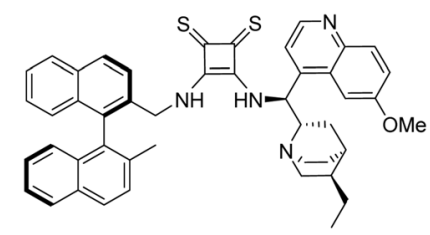

3-(((1S)-((2S,4S,5R)-5-Ethylquinuclidin-2-yl)(6-methoxyquinolin-4$y l) m e t h y l)$ amino $)-4-(S)-\left(\left(\left(2^{\prime}-\right.\right.\right.$ methyl-[1,1'-binaphthalen]-2-yl)methyl)amino)cyclobut-3-ene-1,2-dithione (1d). Orange crystals $(72 \mathrm{mg}$, 86\%). TLC (aluminium oxide TLC; chloroform:methanol: $\left.\mathrm{NH}_{3}=40: 1: 0.01\right) R_{\mathrm{f}}=0.66 ;\left(\mathrm{SiO}_{2} \mathrm{TLC} ;\right.$ chloroform $:$ methanol $=$ $\left.40: 1: 0.01 \mathrm{NH}_{3}\right) R_{\mathrm{f}}=0.25$. M.p. $208-210{ }^{\circ} \mathrm{C},[\alpha]_{20}^{\mathrm{D}}-93.3(\mathrm{c} 1.00$, $\mathrm{CHCl}_{3}$ ); IR $\nu_{\max } 3431,2929,1698,1566,1508,1474,1244,1145$, 1086, 1029, 813, $746 \mathrm{~cm}^{-1} ;{ }^{1} \mathrm{H}$ NMR $\delta$ (ppm, $600 \mathrm{MHz}, \mathrm{DMSO}_{6}$, $\left.22{ }^{\circ} \mathrm{C}\right) 0.76\left(3 \mathrm{H}, t, J_{\mathrm{H}, \mathrm{H}} 7.3 \mathrm{~Hz}\right), 1.25(2 \mathrm{H}, \mathrm{b}), 1.35(2 \mathrm{H}, \mathrm{m}), 1.44$ (1 H, b), 1.47 (1 H, b), $1.56(1 \mathrm{H}, \mathrm{b}), 1.98(3 \mathrm{H}, \mathrm{s}), 1.81(1 \mathrm{H}, \mathrm{b})$, 2.43 (1 H, b), 2.60 (1 H, b), 3.16 (1 H, b), 3.67 (1 H, b), 4.00 $(1 \mathrm{H}, \mathrm{b}), 4.02(3 \mathrm{H}, \mathrm{s}), 4.89\left(1 \mathrm{H}, \mathrm{d}, J_{\mathrm{H}, \mathrm{H}} 14.6 \mathrm{~Hz}\right), 5.13\left(1 \mathrm{H}, \mathrm{d}, J_{\mathrm{H}, \mathrm{H}}\right.$ $14.6 \mathrm{~Hz}), 6.73(1 \mathrm{H}, \mathrm{b}), 6.82(1 \mathrm{H}, \mathrm{b}), 6.86\left(1 \mathrm{H}, \mathrm{d}, J_{\mathrm{H}, \mathrm{H}} 8.5 \mathrm{~Hz}\right)$, 6.96 (1 H, b), 7.28 (1 H, m), 7.48 (1 H, m), 7.49 (1 H, m), 7.50 $(1 \mathrm{H}, \mathrm{m}), 7.61(1 \mathrm{H}, \mathrm{b}), 7.72(1 \mathrm{H}, \mathrm{b}), 7.79\left(1 \mathrm{H}, \mathrm{d}, J_{\mathrm{H}, \mathrm{H}} 8.5 \mathrm{~Hz}\right), 7.86$ $\left(1 \mathrm{H}, \mathrm{d}, J_{\mathrm{H}, \mathrm{H}} 8.4 \mathrm{~Hz}\right), 8.00(1 \mathrm{H}, \mathrm{m}), 8.01(1 \mathrm{H}, \mathrm{m}), 8.02(1 \mathrm{H}, \mathrm{m})$, $8.10\left(1 \mathrm{H}, \mathrm{d}, J_{\mathrm{H}, \mathrm{H}} 8.5 \mathrm{~Hz}\right), 8.83\left(1 \mathrm{H}, \mathrm{d}, J_{\mathrm{H}, \mathrm{H}} 4.3 \mathrm{~Hz}\right) ;{ }^{13} \mathrm{C} \mathrm{NMR} \delta$ (ppm, $150 \mathrm{MHz}, \mathrm{DMSO}_{6}, 22{ }^{\circ} \mathrm{C}$ ) 12.0, 20.2, 22.3, 24.0, 25.4, 27.6, 36.5, 41.1, 44.9, 56.0, 56.4, 57.0, 102.7, 120.2, 122.5, 124.7, 124.7, 125.2, 125.4, 126.3, 126.6, 127.1, 127.3, 128.0, 128.2, 128.4, 128.6, 129.0, 131.6, 131.9, 132.1, 132.4, 132.5, 133.0, 134.4, 134.8, 135.5, 144.5, 147.9, 158.0, 168.8, 171.2, 201.0, 204.3; HRMS-ESI $^{+}$ $(m / z):\left[\mathrm{M}+\mathrm{H}^{+}\right]$calcd for $\mathrm{C}_{46} \mathrm{H}_{45} \mathrm{~N}_{4} \mathrm{~S}_{2} \mathrm{O}: 733.3035$, found: 733.3043 .

To the best of our knowledge the synthesis of $1 \mathbf{d}$ has not been reported.

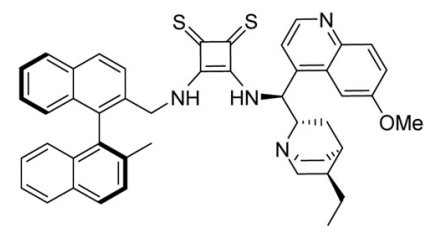

General procedure for Michael addition of pentane-2,4-dione to trans- $\beta$-nitrostyrene. To a solution of trans- $\beta$-nitrostyrene (7) (23.4 $\mathrm{mg}, 0.16 \mathrm{mmol})$ in the corresponding solvent $(1 \mathrm{~mL})$, organocatalyst 1a, 1b, 1c or $\mathbf{1 d}$ was added. Then pentane-2,4-dione (8)
(41.5 $\mu \mathrm{L}, 40.7 \mathrm{mg}, 0.41 \mathrm{mmol}$ ) was added to this solution and the resulting reaction mixture was stirred at room temperature. After the reaction was completed, the volatile components were removed under reduced pressure. The crude product was purified by preparative thin layer chromatography on silica gel using hexane : ethyl acetate $2: 1$ mixture $\left(R_{\mathrm{f}}=0.36\right)$ as eluent to obtain Michael adduct as pale-yellow crystals. Yields and enantiomeric excess (ee) values can be seen in Tables 1,2 and 5. These products had the same spectroscopic data than those of reported (the absolute configuration was determined by the optical rotation of the products). ${ }^{29}$ HPLC: Phenomonex Lux Cellulose- 3 column $(3 \mu \mathrm{m}, 250 \times 4.6 \mathrm{~mm})$, eluent $\mathrm{CH}_{3} \mathrm{CN} / 20 \mathrm{mM}$ $\mathrm{NH}_{4} \mathrm{OAc}$ in $\mathrm{H}_{2} \mathrm{O}=40 / 60$, isocratic mode; $0.6 \mathrm{~mL} \mathrm{~min}^{-1}$; UV detector $222 \mathrm{~nm}, 5 \mu \mathrm{L}$ or $10 \mu \mathrm{L}$ injection, $20{ }^{\circ} \mathrm{C}$. Retention time for (S)-9: $11.94 \mathrm{~min}$, for $(R)-9: 14.20 \mathrm{~min}$. The applied solvents, the amounts of the catalysts and reaction times are shown in Tables 1, 2 and 5.

General procedure for conjugate addition reaction of lawsone to $\boldsymbol{\beta}, \boldsymbol{\gamma}$-unsaturated $\boldsymbol{\alpha}$-keto ester. To a solution of 1 awsone (10) $(17.4 \mathrm{mg}, 0.10 \mathrm{mmol})$ in dichloromethane $(0.5 \mathrm{~mL})$, organocatalyst $\mathbf{1 a}, \mathbf{1 b}, \mathbf{1 c}$ or $\mathbf{1 d}$ was added. Then $\beta, \gamma$-unsaturated $\alpha$-keto ester (11) $(22.5 \mathrm{mg}, 0.11 \mathrm{mmol})$ was added to this solution and the resulting reaction mixture was stirred $1 \mathrm{~h}$ at room temperature. After the reaction was completed, the volatile components were removed under reduced pressure. The crude product was purified by preparative thin layer chromatography on silica gel using hexane : ethyl acetate $2: 1$ mixture $\left(R_{\mathrm{f}}=0.30\right)$ as eluent to obtain adduct 12 as yellow crystals. Yields and enantiomeric excess (ee) values can be seen in Tables 3 and 6 . These products had the same spectroscopic data than those of reported (the absolute configuration was determined by the optical rotation of the products). ${ }^{48}$ HPLC: Phenomonex Lux Cellulose-1 column $(3 \mu \mathrm{m}, 250 \times 4.6 \mathrm{~mm})$; eluent $\mathrm{CH}_{3} \mathrm{CN} / 0.1 \%$ AcOH in $\mathrm{H}_{2} \mathrm{O}$ and $=40: 60$, isocratic mode; $0.8 \mathrm{~mL} \mathrm{~min}^{-1}$; UV detector $222 \mathrm{~nm} ; 5 \mu \mathrm{L}$ or $10 \mu \mathrm{L}$ injection, $25{ }^{\circ} \mathrm{C}$. Retention time for $(R)$-12: $9.16 \mathrm{~min}$, for $(S)$-12: $10.87 \mathrm{~min}$. The amounts of the catalysts are shown in Tables 3 and 6.

General procedure for aza-Diels-Alder reaction of 2-siloxydiene to $\mathrm{N}$-benzylideneaniline. To a solution of $\mathrm{N}$-benzylideneaniline (14) (18 mg, $0.10 \mathrm{mmol})$ in toluene $(0.5 \mathrm{~mL})$, organocatalyst 1a, 1b, 1c or 1d was added. Then 2-siloxydiene (13) (31 $\mathrm{mg}, 0.12 \mathrm{mmol}$ ) was added to this solution and the resulting reaction mixture was stirred at room temperature for $12 \mathrm{~h}$. After the reaction was completed, the volatile components were removed under reduced pressure. The crude product was purified by preparative thin layer chromatography on neutralised aluminium oxide gel using hexane $\left(R_{\mathrm{f}}=0.40\right)$ as eluent to obtain aza-Diels-Alder adduct as pale-yellow crystals. Yields and diastereomeric ratio ( $\mathrm{dr}$ ) values can be seen in Table 4 . These products had the same spectroscopic data than those of reported. ${ }^{49}$

\section{Conflicts of interest}

There are no conflicts to declare. 


\section{Acknowledgements}

This research was funded by the New National Excellence Program of the Ministry of Human Capacities, grant numbers ÚNKP-18-4-BME-270 and ÚNKP-18-2-II-BME-243, and the Janos Bolyai Research Scholarship of the Hungarian Academy of Sciences. It was also supported by the National Research, Development and Innovation office (former OTKA, grant number K128473), the Servier-Beregi PhD Research Fellowship, and the Gedeon Richter's Talentum Foundation. The authors are grateful to Zsófia Garádi from Budapest University of Technology and Economics and to Dr András Dancsó from Egis Pharmaceuticals Plc., Directorate of Drug Substance Development for their assistance with the NMR measurements.

\section{Notes and references}

1 P. I. Dalko and L. Moisan, Angew. Chem., Int. Ed., 2001, 40, 3726-3748.

2 K. N. Houk and B. List, Acc. Chem. Res., 2004, 37, 487.

3 D. W. C. MacMillan, Nature, 2008, 455, 304-308.

4 G. Zhan, W. Du and Y. C. Chen, Chem. Soc. Rev., 2017, 46, 1675-1692.

5 D. L. Hughes, Org. Process Res. Dev., 2018, 22, 574-584.

6 Y. Chen, S. Yekta and A. K. Yudin, Chem. Rev., 2003, 103, 3155-3211.

7 P. Kocovsky, S. Vyskocil and M. Smrcina, Chem. Rev., 2003, 103, 3213-3245.

8 J. M. Brunel, Chem. Rev., 2005, 105, 857-897.

9 D. Kampen, C. M. Reisinger and B. List, Top. Curr. Chem., 2009, 291, 395-456.

10 S. Schenker, A. Zamfir, M. Freund and S. B. Tsogoeva, Eur. J. Org. Chem., 2011, 2209-2222.

11 D. Parmar, E. Sugiono, S. Raja and M. Rueping, Chem. Rev., 2014, 114, 9047-9153.

12 R. B. Sunoj, Acc. Chem. Res., 2016, 49, 1019-1028.

13 B. Liu, X. Han, Z. Dong, H. Lv, H. B. Zhou and C. N. Dong, Tetrahedron: Asymmetry, 2013, 24, 1276-1280.

14 E. S. Zhou, B. Liu and C. N. Dong, Tetrahedron: Asymmetry, 2014, 25, 181-186.

15 S. Tang, Z. Y. Wang, B. Liu and C. E. Dong, Chin. Chem. Lett., 2015, 26, 744-748.

16 V. Modrocka, E. Veverkova, R. Baran and R. Sebesta, ChemistrySelect, 2018, 3, 1466-1471.

17 C. Jin, M. Zhang, L. Wu, Y. F. Guan, Y. Pan, J. L. Jiang, C. Lin and L. Y. Wang, Chem. Commun., 2013, 49, 2025-2027.

18 X. Han, H. B. Zhou and C. E. Dong, Chem. Rec., 2016, 16, 897-906.

19 M. Chennapuram, U. V. S. Reddy, C. Seki, Y. Okuyama, E. Kwon, K. Uwai, M. Tokiwa, M. Takeshita and H. Nakano, Eur. J. Org. Chem., 2017, 1638-1646.

20 B. L. Zhao, J. H. Li and D. M. Du, Chem. Rec., 2017, 17, 994-1018.

21 L. J. Yan, G. X. Huang, H. F. Wang, F. J. Xiong, H. H. Peng and F. Chen, Eur. J. Org. Chem., 2018, 99-103.

22 M. Rombola and V. H. Rawal, Org. Lett., 2018, 20, 514-517.
23 S. Nagy, P. Kisszekelyi and J. Kupai, Period. Polytech., Chem. Eng., 2018, 62, 467-475.

24 T. X. Lu and S. E. Wheeler, Chem. - Eur. J., 2013, 19, 15141-15147.

25 M. P. Doyle, J. P. Morgan, J. C. Fettinger, P. Y. Zavalij, J. T. Colyer, D. J. Timmons and M. D. Carducci, J. Org. Chem., 2005, 70, 5291-5301.

26 B. Bhaskararao and R. B. Sunoj, J. Am. Chem. Soc., 2015, 137, 15712-15722.

27 P. C. B. Page, B. R. Buckley and A. J. Blacker, Org. Lett., 2004, 6, 1543-1546.

28 S. Nagy, Z. Feher, P. Kisszekelyi, P. Huszthy and J. Kupai, New J. Chem., 2018, 42, 8596-8602.

29 C. Didaskalou, J. Kupai, L. Cseri, J. Barabas, E. Vass, T. Holtzl and G. Szekely, ACS Catal., 2018, 8, 7430-7438.

30 S. H. McCooey and S. J. Connon, Org. Lett., 2007, 9, 599-602. 31 R. B. P. Elmes, N. Busschaert, D. D. Czech, P. A. Gale and K. A. Jolliffe, Chem. Commun., 2015, 51, 10107-10110.

32 J. Bergman, B. Pettersson, V. Hasimbegovic and P. H. Svensson, J. Org. Chem., 2011, 76, 1546-1553.

33 D. Prat, J. Hayler and A. Wells, Green Chem., 2014, 16, 4546-4551.

34 T. Welton, Proc. R. Soc. A, 2015, 471, 20150502.

35 C. M. Alder, J. D. Hayler, R. K. Henderson, A. M. Redman, L. Shukla, L. E. Shuster and H. F. Sneddon, Green Chem., 2016, 18, 3879-3890.

36 J. P. Malerich, K. Hagihara and V. H. Rawal, J. Am. Chem. Soc., 2008, 130, 14416-14417.

37 J. Aleman, A. Parra, H. Jiang and K. A. Jorgensen, Chem. Eur. J., 2011, 17, 6890-6899.

38 D. S. Pedersen and C. Rosenbohm, Synthesis, 2001, 2431-2434.

39 J. D. Chai and M. Head-Gordon, Phys. Chem. Chem. Phys., 2008, 10, 6615-6620.

40 P. C. Hariharan and J. A. Pople, Theor. Chim. Acta, 1973, 28, 213-222.

41 Y. H. Shao, Z. T. Gan, E. Epifanovsky, A. T. B. Gilbert, M. Wormit, J. Kussmann, A. W. Lange, A. Behn, J. Deng, X. T. Feng, D. Ghosh, M. Goldey, P. R. Horn, L. D. Jacobson, I. Kaliman, R. Z. Khaliullin, T. Kus, A. Landau, J. Liu, E. I. Proynov, Y. M. Rhee, R. M. Richard, M. A. Rohrdanz, R. P. Steele, E. J. Sundstrom, H. L. Woodcock, P. M. Zimmerman, D. Zuev, B. Albrecht, E. Alguire, B. Austin, G. J. O. Beran, Y. A. Bernard, E. Berquist, K. Brandhorst, K. B. Bravaya, S. T. Brown, D. Casanova, C. M. Chang, Y. Q. Chen, S. H. Chien, K. D. Closser, D. L. Crittenden, M. Diedenhofen, R. A. DiStasio, H. Do, A. D. Dutoi, R. G. Edgar, S. Fatehi, L. Fusti-Molnar, A. Ghysels, A. Golubeva-Zadorozhnaya, J. Gomes, M. W. D. HansonHeine, P. H. P. Harbach, A. W. Hauser, E. G. Hohenstein, Z. C. Holden, T. C. Jagau, H. J. Ji, B. Kaduk, K. Khistyaev, J. Kim, J. Kim, R. A. King, P. Klunzinger, D. Kosenkov, T. Kowalczyk, C. M. Krauter, K. U. Lao, A. D. Laurent, K. V. Lawler, S. V. Levchenko, C. Y. Lin, F. Liu, E. Livshits, R. C. Lochan, A. Luenser, P. Manohar, S. F. Manzer, S. P. Mao, N. Mardirossian, A. V. Marenich, S. A. Maurer, 
N. J. Mayhall, E. Neuscamman, C. M. Oana, R. OlivaresAmaya, D. P. O’Neill, J. A. Parkhill, T. M. Perrine, R. Peverati, A. Prociuk, D. R. Rehn, E. Rosta, N. J. Russ, S. M. Sharada, S. Sharma, D. W. Small, A. Sodt, T. Stein, D. Stuck, Y. C. Su, A. J. W. Thom, T. Tsuchimochi, V. Vanovschi, L. Vogt, O. Vydrov, T. Wang, M. A. Watson, J. Wenzel, A. White, C. F. Williams, J. Yang, S. Yeganeh, S. R. Yost, Z. Q. You, I. Y. Zhang, X. Zhang, Y. Zhao, B. R. Brooks, G. K. L. Chan, D. M. Chipman, C. J. Cramer, W. A. Goddard, M. S. Gordon, W. J. Hehre, A. Klamt, H. F. Schaefer, M. W. Schmidt, C. D. Sherrill, D. G. Truhlar, A. Warshel, X. Xu, A. AspuruGuzik, R. Baer, A. T. Bell, N. A. Besley, J. D. Chai, A. Dreuw, B. D. Dunietz, T. R. Furlani, S. R. Gwaltney, C. P. Hsu, Y. S. Jung, J. Kong, D. S. Lambrecht, W. Z. Liang, C. Ochsenfeld, V. A. Rassolov, L. V. Slipchenko, J. E. Subotnik, T. Van Voorhis, J. M. Herbert, A. I. Krylov, P. M. W. Gill and M. Head-Gordon, Mol. Phys., 2015, 113, 184-215.
42 W. Yang, Y. M. Cui, J. F. Zou, C. Y. Wang, W. S. Huang, J. Zhang and L. W. Xu, Synth. Commun., 2014, 44, 3173-3182.

43 P. Kisszekelyi, A. Alammar, J. Kupai, P. Huszthy, J. Barabas, T. Holtzl, L. Szente, C. Bawn, R. Adams and G. Szekely, J. Catal., 2019, 371, 255-261.

44 C. J. Cramer and D. G. Truhlar, Acc. Chem. Res., 2008, 41, 760-768.

45 The PyMOL Molecular Graphics System, V. S., LLC.

46 C. Cassani, R. Martin-Rapun, E. Arceo, F. Bravo and P. Melchiorre, Nat. Protoc., 2013, 8, 325-344.

47 B. Vakulya, S. Varga, A. Csampai and T. Soos, Org. Lett., 2005, 7, 1967-1969.

48 Y. J. Gao, Q. Ren, S. M. Ang and J. Wang, Org. Biomol. Chem., 2011, 9, 3691-3697.

49 K. Takasu, N. Shindoh, H. Tokuyama and M. Ihara, Tetrahedron, 2006, 62, 11900-11907. 